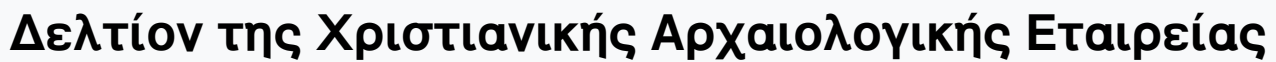

Tó 36 (2015)

$\Delta \varepsilon \lambda$ tíov XAE 36 (2015), Пврíoঠos $\Delta^{\prime}$

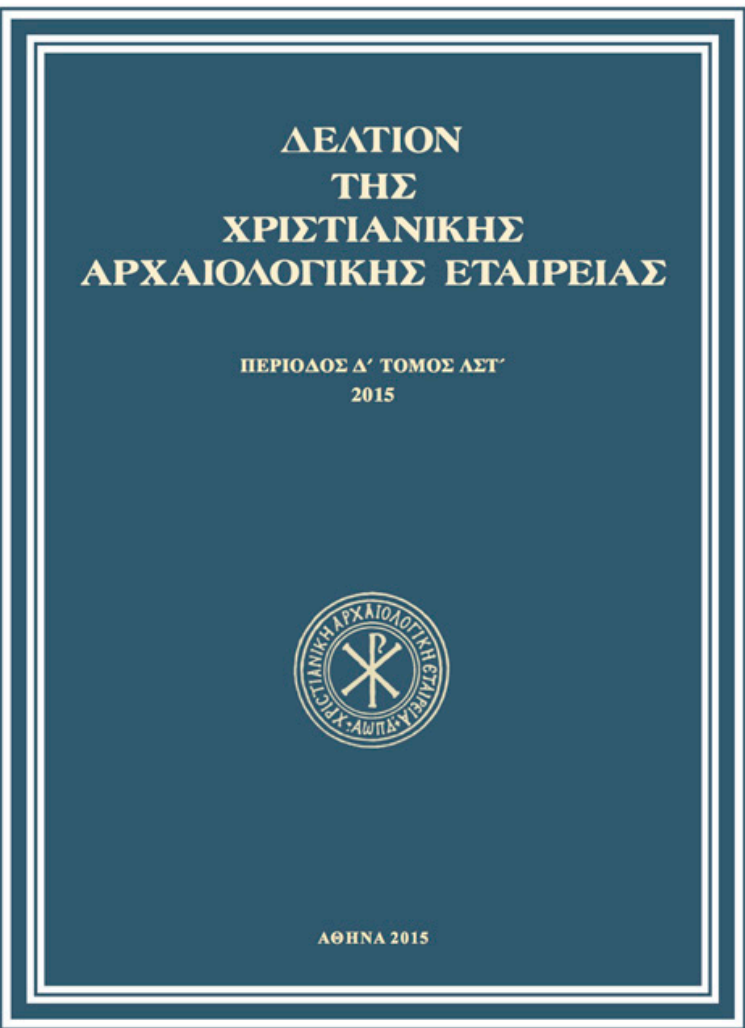

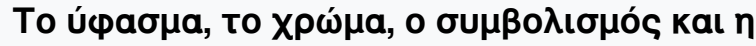

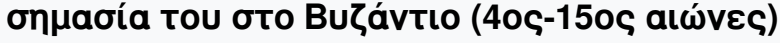

Anna MYTHESIUS

doi: $10.12681 /$ dchae. 1793

Copyright (c) 2016, Anna MYTHESIUS

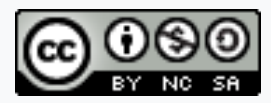

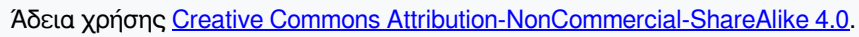

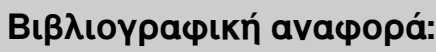

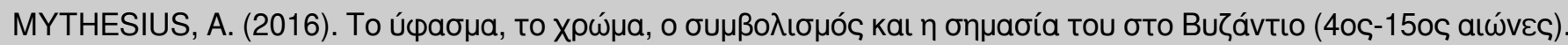

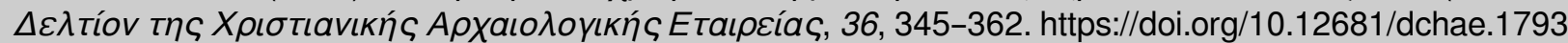


Anna Muthesius

\section{SILK, CULTURE AND BEING IN BYZANTIUM: HOW FAR DID PRECIOUS CLOTH ENRICH "MEMORY" AND SHAPE “CULTURE” ACROSS THE EMPIRE (4th-15th centuries)?}

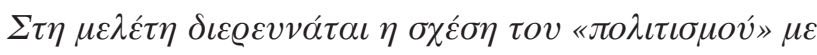

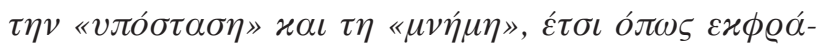

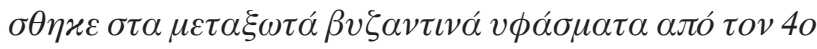

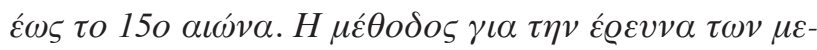

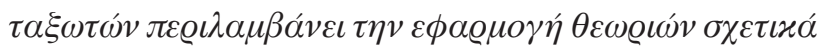

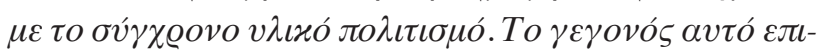

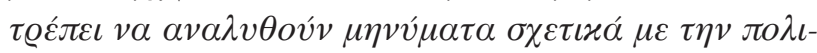

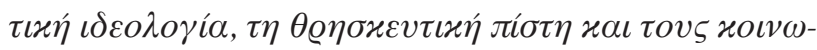

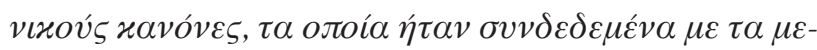

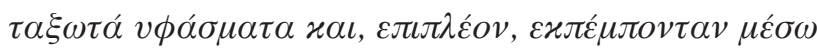

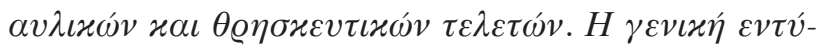
$\pi \omega \sigma \eta$ aлó $\tau \alpha \mu \varepsilon \tau \alpha \xi \omega \tau \alpha \dot{~ \varepsilon i ́ v \alpha \iota ~ o ́ \tau \iota ~ \alpha v \tau \alpha ́ ~ \alpha \pi o \tau \varepsilon \lambda o v ́ \sigma \alpha v ~}$

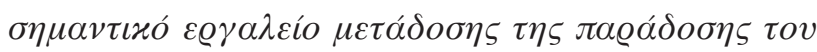

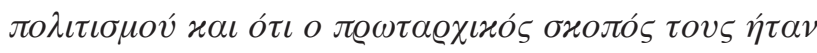

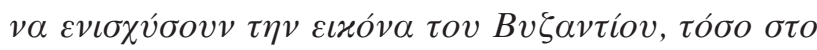

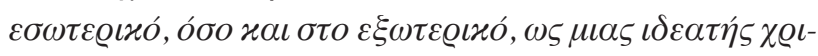

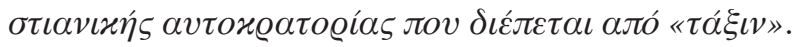

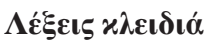

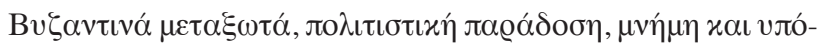

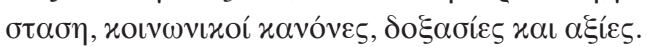

$\mathrm{T}$ his paper explores the relationship between "culture," "being" and "memory" in the context of the use of precious cloth in Byzantium between the 4th and the 15th centuries. It asks the question, How far did precious cloth enrich "memory" and shape "culture" across the Empire over a millennium of time? The paper is arranged under three headings: I. Being; II. Belief Systems and III. Social Process.

\section{Method and Definition of Terms}

Several thousand precious Byzantine textile artefacts, hundreds of written reports concerning their uses, and many visual images of Byzantine textiles and costumes survive (Fig. 1). ${ }^{1}$ This provides a rich ground for investigation of "memory"
The article investigates the relationship of "culture" to "being" and "memory" as expressed on Byzantine silks of the 4th-15th centuries. The method used to explore the silks includes application of contemporary material culture theory. This allows analysis of how messages about political ideology, religious belief and social norms were embedded in the silks and then how these messages were communicated via ceremonial and ritual enactment. The overall impression given by the silks is that they were an important tool for cultural tradition transmission and that their prime purpose was to enhance the image of Byzantium at home and abroad, as a well ordered and idealised Christian Empire.

\section{Keywords}

Byzantine silks, cultural tradition, memory and being, social norms, beliefs and values.

\footnotetext{
* Fellow of the McDonald Institute for Archaeological Research, Fellow Commoner of Lucy Cavendish College, University of Cambridge,amuthesius@yahoo.co.uk

${ }^{1}$ The surviving Byzantine silks were technically analysed, dated and discussed in A. Muthesius, Byzantine Silk Weaving, Vienna 1997. Specific early Byzantine silks as well as further later Byzantine and post Byzantine silks were analysed and set into historical/religious/social/political context in three volumes of collected studies by the same author. See, A. Muthesius, Studies in Byzantine and Islamic Silk Weaving, London 1995; Ead., Studies in Silk in Byzantium, London 2004, and Ead., Studies in Byzantine, Islamic and Near Eastern Silk Weaving, London 2008. For the field of Byzantine dress refer to, P. Kalamara, Le système vestimentaire à Byzance du 4ème jusqu'au 11ème siècle, Lille 1997.
} 


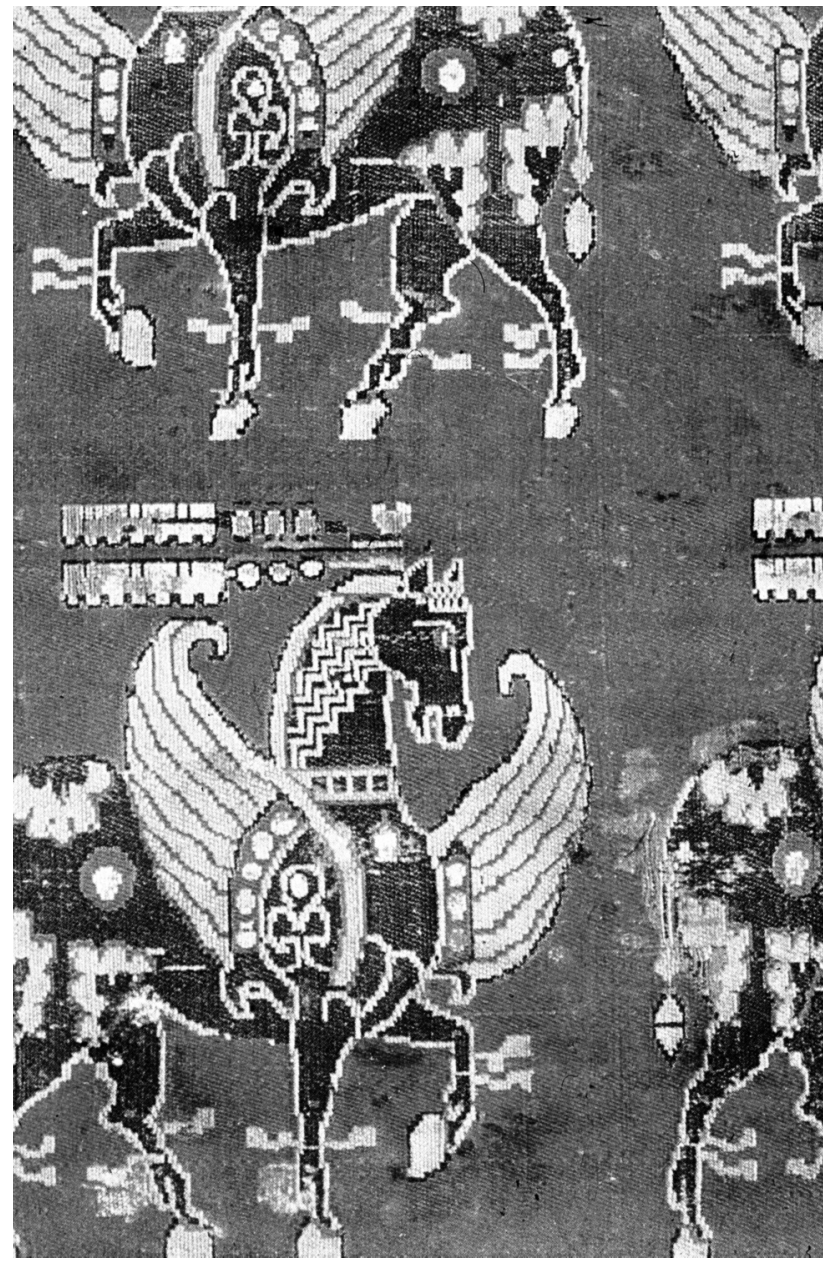

Fig. 1. Rome, Vatican, Museo Sacro. Pegasus silk, 8th to 9th century, Byzantine.

and of "cultural transmission" across a single category of artefact in Byzantium, and it calls for the application of fresh approaches to Byzantine cultural research. Increasingly, contemporary theoretical research on human cognition builds up useful models concerning cognition and cultural transmission across society, and this lecture explores how well such theory, in combination with traditional Byzantine research methods, may be applied to Byzantine Material Culture studies, and in particular to Byzantine textiles and dress. The present author has produced a chart, which outlines the key approaches to material culture studies in Byzantine fields (Fig. 2). ${ }^{2}$

The advantage in this method is that the definitions of key terms as taken from contemporary theory are sufficiently broad and abstract as to be applicable across societies and over millennia of time. "Culture" is defined as "the site of shared concepts and norms, which can be transmitted," and it is seen as being active across "all forms and results of human activity." "Cultural transmission" is defined as the transfer of "concepts and norms" across minds. "Concepts and norms" are defined as "systems of common belief and value," transmitted between minds as "mental units of culture" (memes), in human speech and action. 5

According to this contemporary theoretical model, "concepts and norms" can be embedded into cultural artefacts, and through practices associated with these, ideas can be passed between minds and an ordered environment can be created. Memory is important, in so far as it informs representation attached to, as well as practices associated with artefacts. In "cultural transmission," "memory" as defined here is both "explicit" and "implicit," and it operates in three ways:

\footnotetext{
${ }^{2}$ Relevant here are, P. Boyer - J. V. Wertsch, Memory in Mind and Culture, Cambridge 2009. Also, refer to Cognition and Material Culture: the Archaeology of Symbolic Storage (eds C. Renfrew - C. Scarre), Cambridge 1998, chapters 1, 4, 15. For further archaeological, anthropological and material culture theory perspectives on the role of objects in the development of culture, note E. De Marrais -C. Gosden - C. Renfrew, Rethinking Materiality: the Engagement of Mind with the Material World, Cambridge 2004. Most recently see, D. Elder-Vass, The Reality of Social Construction, New York 2012, for discussion of the relation of material object to use of symbols and cognition, albeit in more recent historical context. For the chart see Muthesius, Studies in Byzantine, Islamic and Near Eastern Weaving, op.cit. (n. 1), fig. on p. 243.
}

${ }^{3}$ Also described as a "shared set of practices and understandings," see Elder-Vass, op.cit. (n. 2), chapter 3, Culture and Rules, p. 37-54, esp. 39. $O D B, \mathrm{I}, 561-562$ presents only a very general definition of "culture."

4 "Cultural transmission" is treated only very briefly in the $O D B, \mathrm{I}$, 562-563. There is no discussion of the nature of the mentalities involved or of individual subjective reaction to cultural norms. ElderVass, op.cit. (n. 2), distinguishes between "subjective and objective moments of culture" and considers that "cultural content" exists as "beliefs of individuals," but attains its "objective aspect" through endorsement by different types of social structures (that is made up of collectives or groups and termed "norm circles"). Key issues about the relation of materiality and material expression in the context of Byzantium were set out as a chart and discussed in detail within a thorough examination of earlier discussions amongst European Byzantine scholars and other academics in, A. Muthesius, "Studies on Material Culture - Some General Considerations," in Muthesius, Byzantine, Islamic and Near Eastern Silk Weaving, op.cit. (n. 1), study XV, especially p. 212-283, with chart on page 243.

${ }^{5}$ Boyer - Wertsch, op.cit. (n. 2), pages 290-292, refers to experimental and development psychology theory to suggest that different minds have similar ways of organising incoming information, which allows distinct individuals to share "norms and concepts" (memes) in common. This is how the transmission of culture occurs between minds. This process is termed "cognitive predisposition." 


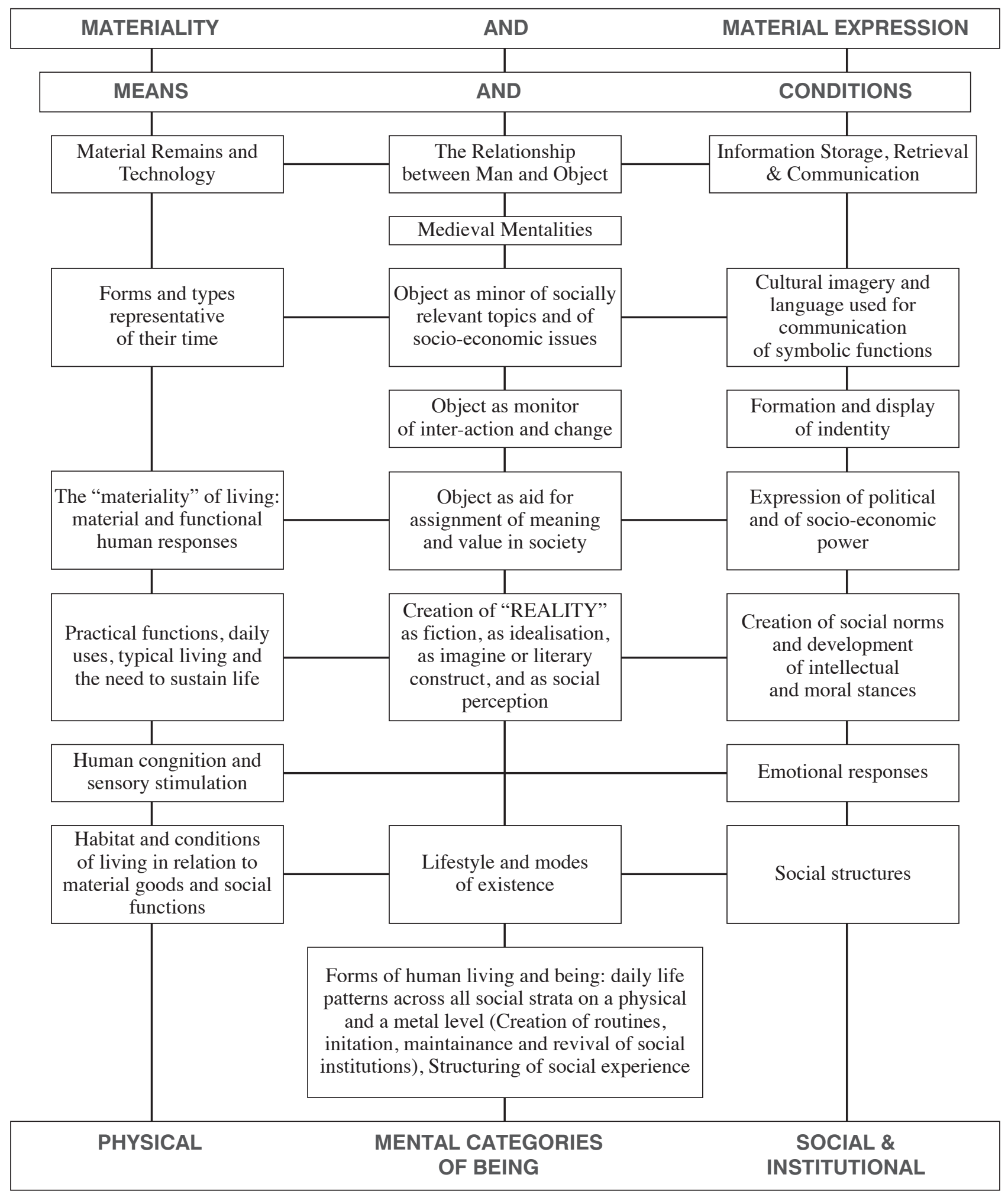

MATERIAL CULTURE: KEY ISSUES

Fig. 2. "Material Culture"chart (Anna Muthesius). 
- explicitly (with reference to direct knowledge of the past), - implicitly (via hidden knowledge embedded in institutional practices: political ceremony, religious ritual etc.), and - implicitly (as part of skills and habits that inform sections of the social fabric). ${ }^{6}$

\section{Being}

The term 'Being' as used in this paper, has two separate definitions:

- collective Roman heritage in relation to ethnicity, and

- individual sense of "true self."

In relation to the first definition centred on questions of Roman identity and the question of ethnicity the traditional image of Byzantium painted by scholars over the last century, pointed to a historically, politically centralised, trans-ethnic Roman Empire, in which each, individual Roman was held to be personally loyal to the Emperor. Religious identity was seen to rest upon the idea of Empire as "oikoumene" with Orthodox rite and Imperial rule cemented together. Culturally, Roman identity was seen as that predominantly based upon use of the Greek language and styles of appearance.

However, after AD 1204, shrinking borders, increased regionalism, and issues of religious compromise (Union of the Churches) had led to a weakening of the sacral dimension of Imperial rule. ${ }^{7}$ Kaldellis argued that Orthodox Christian identity became increasingly detached from Imperial Roman identity from the 13th-15th centuries: "ethnic Romans" (those not loyal to the Emperor) were distinguished in the sources, from the Rhomaioi (those loyal to the State). ${ }^{8}$ Byzantium as "nation State" post AD 1204 rather than as "Imperial Empire" is an idea that he has put forward. How far might such contrasting definitions of Byzantine identity bear individual truth, and if so, both be reflected in the use of precious cloth?

The subject of "Being" in the second sense, that is of discovery of the "true self" as part of personal identity in Byzantium, has still to be explored in relation to cultural artefacts. Byzantine belief was centred upon concepts of self-knowledge gained via the embodied self, aided through reason, an attribute of the higher self. The whole subject of the relation of body/soul, of self-awareness, self-correction, and the relationship between reason and spirituality is important for understanding Byzantine attitudes towards cultural transmission through objects. ${ }^{9}$ A comprehensive rereading of texts to extract specific information about this aspect of Byzantine Material Culture is desirable.
In the field of "Being" as part of identity, Page's book, "Being Byzantine" is relevant. ${ }^{10}$ She tested concepts of "ethnicity" against Byzantine historical documentation. She concluded that the concept of Byzantine Roman identity was transformed following the Latin conquest of AD 1204. After that time, there was no single uniform sense of ethnic identity amongst the Romans. Ethnic identities were not static but developed in response to major political changes, in particular to the Frankish conquest. ${ }^{11}$ Page's observations, concerning how historical circumstance can affect "Being" is relevant in relation to Byzantine textiles and dress, in so far as dress acted as hierarchy, social signifier and medium of social recognition not only in Byzantium but also in the West. ${ }^{12}$

\footnotetext{
${ }^{6}$ Boyer - Wertsch, op.cit. (n. 2), 292, discusses "implicit and explicit cultural acquisition in different domains." On p. 312-313 "the interplay between explicit episodic memory and the largely implicit processes that govern knowledge acquisition and belief fixation" is discussed. In this process physical objects and events serve as cues to trigger inferences. It is common inferential processes across different minds, which allow humans to maintain similar concepts and norms within different social groups, and this underpins a culture. For discussions of these issues across historical time, see further, C. Gosden, Social Being and Time, Oxford 1994. The present author would suggest that similarities between cultures of different civilisations over historic time, as seen for example, in the identical symbolic uses (social, religious and political) of silks across the Byzantine, Islamic, Near and Far Eastern Worlds, implies that universal basic human needs lie behind develop-
} ment of symbolic object/man related culture in general.

${ }^{7}$ A. Kaldellis, Hellenism in Byzantium. The Transformation of Greek Identity and the Reception of the Classical Tradition, Cambridge 2007. ${ }^{8}$ Ibid., 317-397. For the term "Greci" see 336-337, 345-351, 357-368. In the West by the 12th century the use of "Graecus" represented a rejection of Byzantine claims to their Imperial Roman heritage. By the 13th century the use of 'Graecus' also represented the western challenge to Byzantium to rule her own lands. See p. 360-388 for the rise of Hellenism in this context. See further, n. 10 below.

${ }^{9}$ The concepts of "body" and "soul" are discussed in the $O D B$, I, 299, and in III, 1931-1932. See further, G. Podskalsky, Theologie und Philosophie in Byzanz, Munich 1977.

${ }^{10}$ G. Page, Being Byzantine. Greek Identity before the Ottomans, Cambridge 2008, 267-281. Cf. ODB, III, 1793 for the ethnic term "Rhomaios" in contrast to "Graikos." The $O D B$ entry argues that mainly the state used the former term, whilst the latter term generally appeared in a religious context.

${ }^{11}$ Page, op.cit. (n. 10), 267-281.

12 A. Muthesius, "Textiles as Text," Wonderful Things: Byzantium through its Art, XLII Spring Symposium of Byzantine Studies (London, 20-22 March 2009) (eds A. Eastmond - L. James), Farnham 2013, 185202. Also see Muthesius, Byzantine, Islamic and Near Eastern Silk Weaving, op.cit. (n. 1), 31-37 and Ead., Silk in Byzantium, op.cit. (n. 1), 67-84. J. L. Ball, Byzantine Dress. Representations of Secular Dress in 8th-12th Century Painting, New York - Basingstoke 2005, is an art historical study and lacks textile expertise or technical analysis as part of its method. Ball's criteria for stating which surviving pieces are 
a. Dress as Hierarchy, Social Signifier and Medium of Social Recognition

Being and identity whether Roman or ethnic, was expressed through dress and dress codes mattered to the Byzantines. From the legal prohibitions upon the use of certain tailored, restricted purple silks reserved for Imperial use, to the bans on actresses and prostitutes dressing in costly garments of silk, dress functioned as a hierarchical social signifier, a medium for social recognition, and a moral code (Fig. 3). ${ }^{13}$

When production of silks was increased and decentralised in the 11th to 12th century, women of Constantinople were reported on the streets as wearing fine silk garments from Thebes and Corinth. ${ }^{14}$ This democratisation of luxury outside the Byzantine Imperial court, lower down the social scale, allowed for more individual expression of "Being" in the sense of self-awareness of social image. The messages embodied in the use of fine dress drawn from Imperial practice and filtered through aristocratic circles, lent status to the female citizens of the Capital. But it was not only Byzantine court precedent that would have been influential. Already in the 4th century Diocletian Code, it is evident that many categories of more and less precious silk and purple garments had been sold upon the open market to the citizens of Rome. Roman traditions also have to be considered. ${ }^{15}$

In Byzantine Egypt a social hierarchy of tunics was clearly developed, and the inter-mingling of traditions is even more evident. ${ }^{16}$ By the 5 th to 6 th centuries, linen tunics with woollen tapestry weave panel decoration depicted both secular hunts and scenes with classical themes. One tunic

from Byzantine tailored dress do not stand up in practice. For instance, catalogue number 8 , an earlier Byzantine silk, might well have been tailored in the west later to serve at the translation of the relics of Saint Servatius at Maastricht in 1164. See Muthesius, Byzantine Silk Weaving, op.cit. (n. 1), 73 and n. 92 on p. 79, and catalogue M36 on p. 175176 , for bibliography of the different fragments of this silk, which survive in different locations.

${ }^{13}$ For restricted purple silks refer to J. Koder, Das Eparchenbuch Leons des Weisen [CFHB 33], Wien 1991, sections 8.1-8.4 on p. 102105. For a discussion on purple dyes and an extensive bibliography see, Muthesius, Byzantine Silk Weaving, op.cit. (n. 1), chapter 3, p. 27-33. For the fine dress of prostitutes note, S. Leontsini, Die Prostitution im frühen Byzanz, Wien 1988, 88-89. Michael Psellos detailed a place of refuge for harlots, who had to discard their fine dresses before adopting the habit of nuns. See Michael Psellos, Chronographia IV 36 (I 158-160 Impellizzeri). On propriety of dress see Muthesius, "Textiles and Dress in Byzantium," Material Culture and Well-Being in Byzantium, Cambridge University International Byzantine Conference (8-10 September 2001) (eds M. Grünbart - E. Kislinger - A.

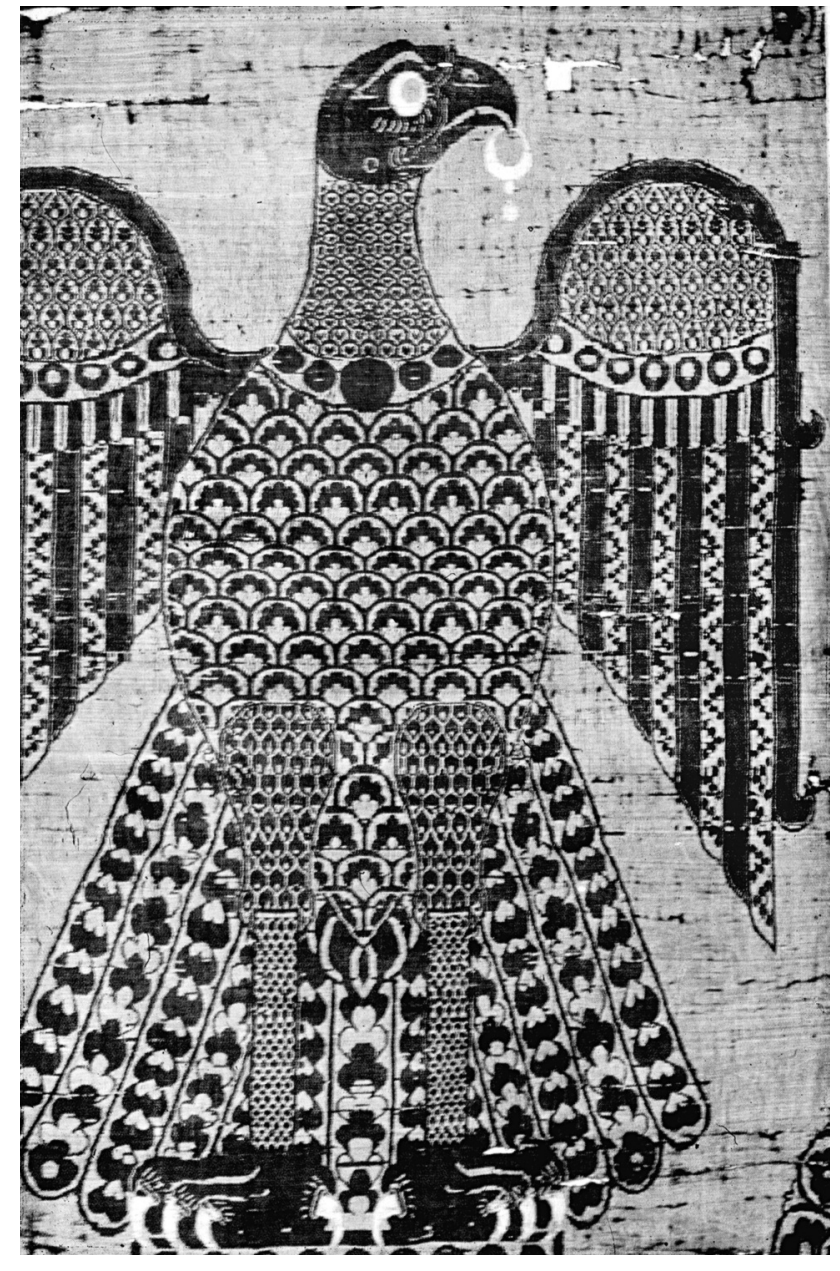

Fig. 3. Brixen, Cathedral treasury. Eagle silk, 10th to 11th century, Byzantine.

Muthesius - D. Stathakopoulos), Vienna 2007, 159-169, especially 164-166.

${ }^{14}$ On silks of Thebes and Corinth consult Niketas Choniates, Chronike Diegesis 461 (ed. J. L. Van Dieten) and E. Kislinger, "Demenna und die byzantinische Seidenproduktion," Byzantinoslavica 54/1 (1993), 43-52, especially 44-45.

${ }^{15}$ S. Lauffer, Diokletians Preisedikt, Berlin 1971. More recently, M. Giacchero, Edictum Diocletiani et collegarum de pretiis rerom venalium, I-II, Genoa 1974. The English translation of T. Frank, The Edict of Diocletian. An Economic Survey of Ancient Rome, V, London 1940, is much earlier. Discussion of the prices of Byzantine silks and dyes as they appear in the Edict, is in G. Steigerwald, "Die Purpursorten im Preisedikt Diokletians vom Jahre 301,” ByzF 15 (1990), 219-276, and in Muthesius, Byzantine and Islamic Silk Weaving, op.cit. (n. 1), 298-303.

${ }^{16}$ D. King, "Roman and Byzantine Dress in Egypt," Collected Textile Studies. Donald King (eds A. Muthesius - M. King), London 2004, study XVI, 246-267. Most recently, see F. Pritchard, Clothing Culture: Dress in Egypt in the First Millennium, Manchester 2006. 
depicts the figure of Dionysius, bears a Christian cross symbol upon the neck, and has prominent shoulder square decoration of Imperial Byzantine type.${ }^{17}$ This "middle-market" range tunic with its amalgamation of concepts of Imperial grandeur, Hellenic heritage and Christian belief, says much about the mentality of some members of the "middling classes" of Byzantine Egypt.

The "luxury-market" range of tunics in Byzantine Egypt, used a similar mixture of images, but were woven in more costly yarns, for example in linen mixed with silk, and they had angora or kashmir goat wool decoration, and also employed the use of costly dyes. ${ }^{18}$ These top range tunics suggest that luxury textile workshops were operating, perhaps in Constantinople, in Alexandria and in centres of Syria prior to the Arab conquest. They also indicate a hierarchy of dress that distinguished "middling" from "higher" strata of Byzantine society in Egypt.

Meanwhile, documentary sources and archaeological finds from Byzantine period sites in Israel, confirm that the ordinary Byzantine wore linen, wool, cotton, or goats hair clothing, whilst documentary sources of the same period, indicate that the poorest and the destitute resorted to old clothes turned inside out, or to rags. ${ }^{19}$ Some types of "working clothing," were depicted in an 11th century Agricultural treatise manuscript: here the ivory carver is in long tunic, whilst the land workers wear short tunics, as do a hunter and a soldier. The latter tunic is tailored to distinguish the soldier's profession. In the same manuscript, an imported Persian fashion is reflected in the depiction of a tight, buttoned short jacket, and elsewhere a female surrounded by what are perhaps servants has on an elaborate, decorated mantle over a thin inner tunic, with a wide turban on her head. In the same manuscript a wrestler appears in a loincloth, and a dancer is shown in a flowing, fancy long tunic. ${ }^{20}$ Dress clearly distinguishes professions and occupations in the miniatures of the Agricultural treatise, in the same way as documentary sources confirm the use of uniforms to authenticate the status of professionals such as judges and the military, as part of the stratification of Byzantine society. ${ }^{21}$

\section{b. Dress as Socially Engendered Behavioural Code}

Dress was also used to communicate socially engendered behavioural codes. Moral codes were built into the use of precious fabrics from an early period, such as that diaphanous cloth, for example, was considered inappropriate for female costume. ${ }^{22}$ Fine silks were considered inappropriate indicators of status for actresses and prostitutes. ${ }^{23}$ At the same time, practical codes were applied to cloth types, and cool fabrics (linen and cotton) were advocated for summer-wear against thick ones (wool), for use in winter, for instance. ${ }^{24}$

Sumptuary laws as such, were not uniformly issued in Byzantium as a standard part of legislation affecting domestic social consumption. However, in the 6th century, when luxury dress of the Imperial court was placed on sale in the "House of Lamps" for use by the "aristocracy" of the Capital, a riot ensued in which the "mob" burnt the venue down. ${ }^{25}$

The Book of the Prefect of the time of Leo VI, documents the importation of foreign luxury clothing into Constantinople, and this Emperor allowed ordinary citizens to include scraps of purple silk decoration on their tunics. ${ }^{26} \mathrm{At}$ this time the wealthy appear to have been permitted to produce at home, high-grade silks for their own domestic consumption, whilst the 10th century Baggage Train account attached to the Book of Ceremonies, also speaks of ordinary

${ }^{17}$ King, op.cit. (n. 16), 263-264 and fig. 12.
${ }^{18}$ Ibid., 265 and fig. 15.
${ }^{19}$ O. Shamir, "Byzantine and Early Islamic Textiles Excavated in ${ }^{19}$ O. Shamir, "Byzantine and Early Islamic Textiles Excavated in
Israel," in A. Muthesius (ed.), Textile History 32/1 (May 2001), 93105 , figs 1-18 and pl. 4. Old clothes and rags worn by the poor are discussed in F. Koukoules, Byzantion, Bios kai politismos, Athens 1949, 3 and 29, with n. 9 citing, Die Gedichte des Christophoros Mytilenaeos (ed. E. Kurtz), 99, 63, and Amasterios of Amasia, PG 40.212. Further related discussion is in Muthesius, Silk in Byzantium, op.cit. (n. 1), 67-84, and Ball, op.cit. (n. 12), 82-85, and 89-98. Ball argues no specific military uniform existed but it is known that silk leggings and other silk tunics were amongst garments carried into battle in the Byzantine Baggage Train. See J. F. Haldon, Constantine Porhyrogenitus. Three Treatises on Imperial Military Expeditions [CFHB 28], Wien 1990, 239-244.

${ }^{20}$ The manuscript is published in I. Furlan, Codici greci illustrati della Biblioteca Marciana, 1-5, Milan 1978-1988, refer to gr. Z479 and see, Muthesius, Silk in Byzantium, op.cit. (n. 1), pl. 78.

${ }^{21}$ John Chrysostom, $P G$ 48, 1035; Sophronius of Jerusalem, $P G 87$, part 3, 3428; Justinian Digest. Cod. 12.39 (ed. E. Kruger); Symeon Metaphrastases, $P G$ 115, as cited by Koukoules, op.cit. (n. 19), 2, part 2, p. 14 .

${ }^{22}$ Discussed in ibid., 6, p. 275 and n. 2.

${ }^{23}$ See ibid., 2, part 2, p. 15 and n. 8-10.

${ }^{24}$ Ibid., 2, part 2, p. 22 and n. 12, citing Asterius of Amaseia, $P G$ 40.165 .

${ }^{25}$ Refer to J. B. Bury, “The Nika Riot,” Journal of Historical Studies 17 (1897), 92-119. J. Evans, "The Nika Rebellion and the Empress Theodora," Byzantion 54 (1984), 380-382. ODB, II, 1473.

${ }^{26}$ For imported silks refer to Koder, op.cit. (n. 13), section 4, p. 9195 and section 5, p. 95-97. For purple scraps of silk see, P. Noailles H. Dain, Les Novelles de Léon VI, le Sage, Paris 1944, 272-274. 


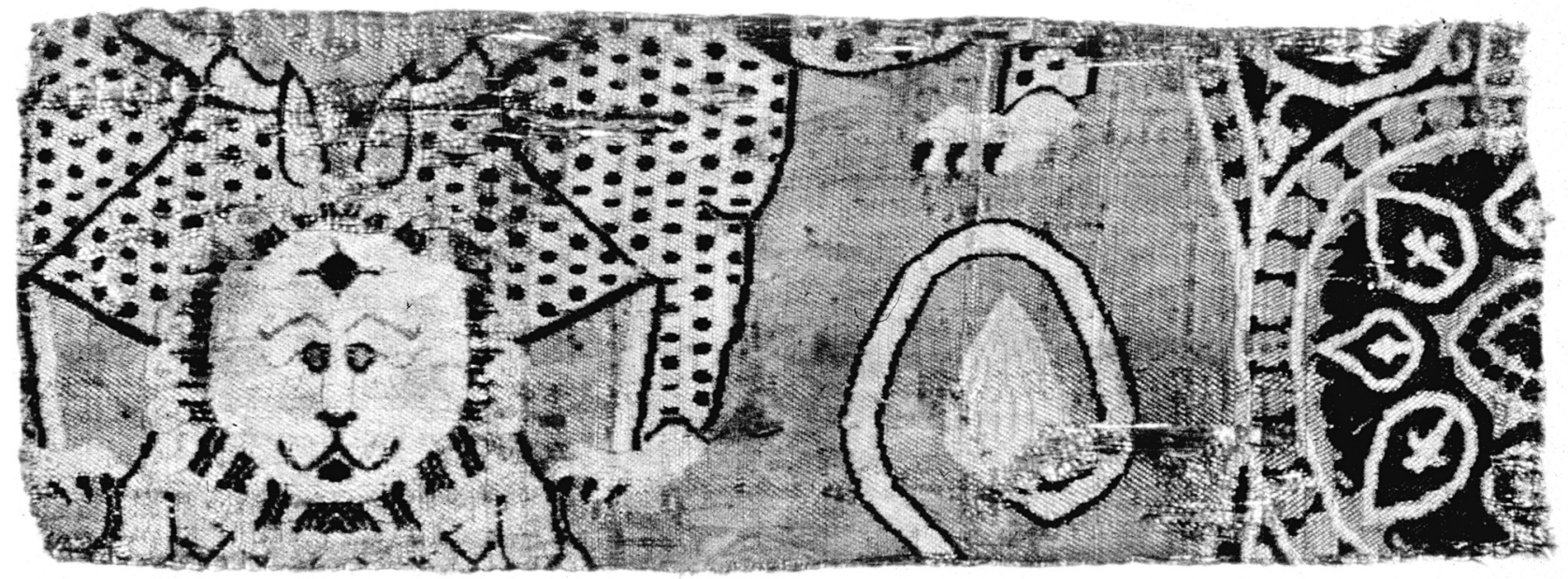

Fig. 4. Aachen, Cathedral treasury. Double-bodied lion silk, 12th century.

tunics imported from Egypt, available on the open market in the Capital. ${ }^{27} \mathrm{~A}$ wide variety of clothing was evidently available to serve all social strata.

Some notion of "national" consciousness through dress is discernible from the 13th century on. Foreign luxury textile imports were banned in Nicaea in the 13th century, and there were complaints about the use of imported fashions instead of local dress, for instance, in Rhodes in the 15 th century. ${ }^{28}$ The Venetian Senate in 1339 issued sumptuary regulations in Crete and also briefly regulated importation of Venetian luxury fabrics into the Morea in the 1430 s but then recanted. ${ }^{29}$ The burial of a Byzantine princess in imported western, tailored silks at Mystra in the 15th century indicates that the lure of foreign fashion did not necessarily argue against Byzantine Imperial identity in the context of the Peloponnese. ${ }^{30}$ The silk chemise and robe of twill with floated weft design and damask respectively, are of two different imported western silks, both perhaps Spanish, and the tailoring is of western type. ${ }^{31}$ The effects of inter-cultural contact on Byzantine identity, as noted by Page, appear here to be reflected in the use of foreign dress. ${ }^{32}$

\section{c. Dress as Popular Culture}

On the level of popular culture, dress images were described in detail within the literary forms of Byzantine epic and poetic writing of the 11th and 12th centuries. In the epic Digenis Akritis, for example, one Roman dress outfit is described as "a marvellous surcoat sprinkled with gold, of purple silk with a white triple border and ornamental griffins." ${ }^{33}$ This
27 J. F. Haldon, Three Treatises on Imperial Military Expeditions [CFHB 28], Wien 1990, C289-290 for bought garments and cf. C226 for imperially produced or commissioned garments. Note also both the victorious and the vanquished wearing special silks in military victory parades as described in A. A. Vasiliev, "Harun Ibn Yahya and his Description of Constantinople," Seminarium Kondakovianum 5 (1932), 149-163, especially 159.

${ }^{28}$ For the silk industry of Nicaea between 1208/1261, and beyond see Theodore Metochites, Nicene Oration (ed./trans. C. Foss), Nicaea. A Byzantine Capital and its Praises, Brookline Mass. 1996, 190-192, chapter 18, lines 12-17. The Emperor Ioannes III Vatatzes (12221254) of Nicaea imposed a ban on the importation of Italian and Turkish silks around 1243. See F. Dölger, Regesten der Kaiserurkunden des oströmischen Reiches, 3, Regesten von 1204-1282 (ed. P. Wirth), Munich 1977, entry number 1777 ( $c a .1243$ ). On the dress of Rhodes refer to Emanuel Georgillas "Limenites," To Thanatikon tes Rhodou, in Bibliothèque grecque Vulgaire (ed. E. Legrand), I, Paris 1880, reprint Athens 1974, 206-209. For female costume of Rhodes see A. Micha-Lampaki, "To Thanatikon tes Rhodou," Byzantinos Domos 3 (1989), 51-62.

${ }^{29}$ In 1339 , sumptuary laws were promulgated by the Venetians to curb excesses in use of luxury dress and jewellery in Crete. Refer to J. Jegerlehner, "Beiträge zur Verwaltungsgeschichte Kandias im XIV. Jahrhunderts," BZ 13 (1904), 464-465, para. 14-22. See also, M. M. Newett, "The Sumptuary Laws of Venice in the Fourteenth and Fifteenth Centuries," Historical Essays (eds T. F. Tout - J. Tait), Manchester 1967, 245-278.

${ }^{30}$ M. Martiani-Reber, Parure dune princesse Byzantine, Geneva 2000, 88 .

${ }^{31}$ See ibid., 37-39, 87-88 and pls on p. 41-44.

${ }^{32}$ Page, op.cit. (n. 10), 243-281.

${ }^{33}$ E. Jeffreys, Digenis Akritis, Cambridge 1998, 59. 
description clearly harks back to images of Imperial dress. Elsewhere, epigrams upon luxurious decorative objects including textiles were also written, providing evidence of critiques of luxury as formulated for public consumption. ${ }^{34}$ However, of special interest is the popular description of a dress fabric bearing the design of lions with twin bodies, for this design has a parallel outside Byzantine literature on an actual silk at Aachen Cathedral as shown here (Fig. 4). ${ }^{35}$ The evidence so far discussed, would suggest that: in the popular imagination, both explicit and implicit "memories" of different categories of dress existed as "mental units of culture;" that concepts and norms were embedded into these categories of dress, and that specific cultural beliefs and values concerning dress were transmitted in written, visual and material form.

\section{Belief Systems}

\section{A. Political Ideology}

a. Power and Authority of the State

Turning now to belief systems in Byzantium and first to political ideology, it is clear that the Image of the Emperor was all-important. The power and authority of the State was embedded in the Emperor, who in theory had to portray an appropriate image of secular might wedded to Christian piety. ${ }^{36}$ Hellenic, Roman, and Byzantine Christian heritage was used to underpin legitimacy of Imperial rule at different periods, and can be detected in Byzantine written, visual and material evidence. Precious textiles were important, and legitimacy was emphasised through the establishment of Imperial silk weaving workshops from the 4th century onwards, which produced Imperial costumes of special cut using a range of exclusive Imperial purple dyes, and gold embroideries. ${ }^{37}$ Particular motifs such as eagles and griffins were used to symbolise the secular and the spiritual attributes of the ruler: in particular the presence of noble ancestors, alongside his noble, brave and generous attributes of character, for example on the Sitten Griffin silk (Fig. 5). ${ }^{38}$ Splendid costumes were essential to support Imperial ceremonial and public display as demonstrated in the Kleterologion of Philotheos of 899, in the compiled 10th century Book of Ceremonies, in the 14th century Treatise of Pseudo Kodinos, and as depicted in luxury court manuscript miniatures. ${ }^{39}$ Through the use of splendid court costume the Emperor produced a sense of awe and promoted loyalty amongst his subjects. A private wardrobe was also available to the Imperial house, and glimpses of what the Emperor's wore outside official ceremony, are found for instance, in the writings of Nicetas Choniates, who characterised Andronicus I as rather a "dandy," who wore particularly body shaping hose, and a fancy hat. ${ }^{40}$ This suggests that two Imperial images based upon dress (public and private), in practice might have existed.

${ }^{34}$ On epigrams of Christophoros Mitylenaios see, N. Oikonomides, "Life and Society in Eleventh Century Constantinople," in N. Oikonomides, Society and Economic Life in Byzantium, Aldershot 2004, study XXI on p. 1-14, and H. Maguire, "Epigrams, Art and the Macedonian Renaissance," in H. Maguire, Image and Imagination in Byzantine Art, Aldershot 2007, study IV on p. 105-115.

${ }^{35}$ Muthesius, Byzantine Silk Weaving, op.cit. (n. 1), 43 and n. 53, silk M622, pl. 107B with reference to C. Cupane, "Review of F. Conca et al., Il Romanzo bizantino del XII secolo, Turin 1994,” BZ 89 (1996), 96-100, especially 99-100 and n. 2. Cupane refers to a description of a bicephal lion textile in Theodori Prodromi de Rhodanthes Dosiclis Amoribus Libri, IX (ed. M. Markovich), Stuttgardiae et Lipsiae 1992. ${ }^{36}$ On the roles of the Emperor and the Patriarch see R. Macrides, "Nomos and Kanon in Paper and in Court," Church and People in Byzantium. Twentieth Spring Symposium of Byzantine Studies (ed. R. Morris), Manchester 1986, 61-85, especially 62-65. On the dual spiritual and secular roles of the Emperor consider, G. Dagron, Emperor and Priest. The Imperial Office in Byzantium, Cambridge 2003. On communication of the roles of the Emperor see G. T. Dennis, "Imperial Panegyric. Rhetoric and Reality," Byzantine Court Culture from 829-1204 (ed. H. Maguire), Washington 1997, 131-140. On triumphal rule as part of the imperial image consult, M. McCormick, Eternal Victory, Cambridge 1990, chapters 4-5 on p. 131-230. Further, for imperial ceremonial in relation to maintenance of symbolic communication of imperial power see A. Cameron, "The Construction of Court Ritual," Rituals of Royalty: Power and Ceremonial in Traditional Societies (eds D. Cannadine - S. Price), Cambridge 1987, 106-136.

${ }^{37}$ A. Muthesius, "The Byzantine Silk Industry: Lopez and Beyond," in Muthesius, Byzantine and Islamic Silk Weaving, op.cit. (n. 1), study XVI, 255-314.

${ }^{38}$ A. Muthesius, "The Byzantine Eagle," in Muthesius, Studies in Silk in Byzantium, op.cit. (n. 1), study XII, 227-236.

${ }^{39}$ See the following works, J. Verpeaux, Traité des offices, Paris 1966 and N. Oikonomides, Les listes de préséance byzantines des IXe et Xe siècle, Paris 1972, 65-235, and A. Grabar, "Pseudo Codinos et les cérémonies de la cour Byzantine au XIV siècle," Art et société à Byzance sous les Paléologues, Venice 1971, 193-221; J. J. Reiske, Constantini Porphyrogeniti Imperatoris de ceremoniis aulae byzantinae, I-II, Bonn 1829-1830, with commentary of A. Vogt, Constantin VII Porphyrogénète, Le livre des cérémonies, 1-4, Paris 1935-1940. The recent translation of the Book of Ceremonies published by the university of Melbourn, has been unavailable to the present author in Britain.

${ }^{40}$ Niketas Choniates, Chronike Diegesis (ed. J. L. Van Dieten), 252. 


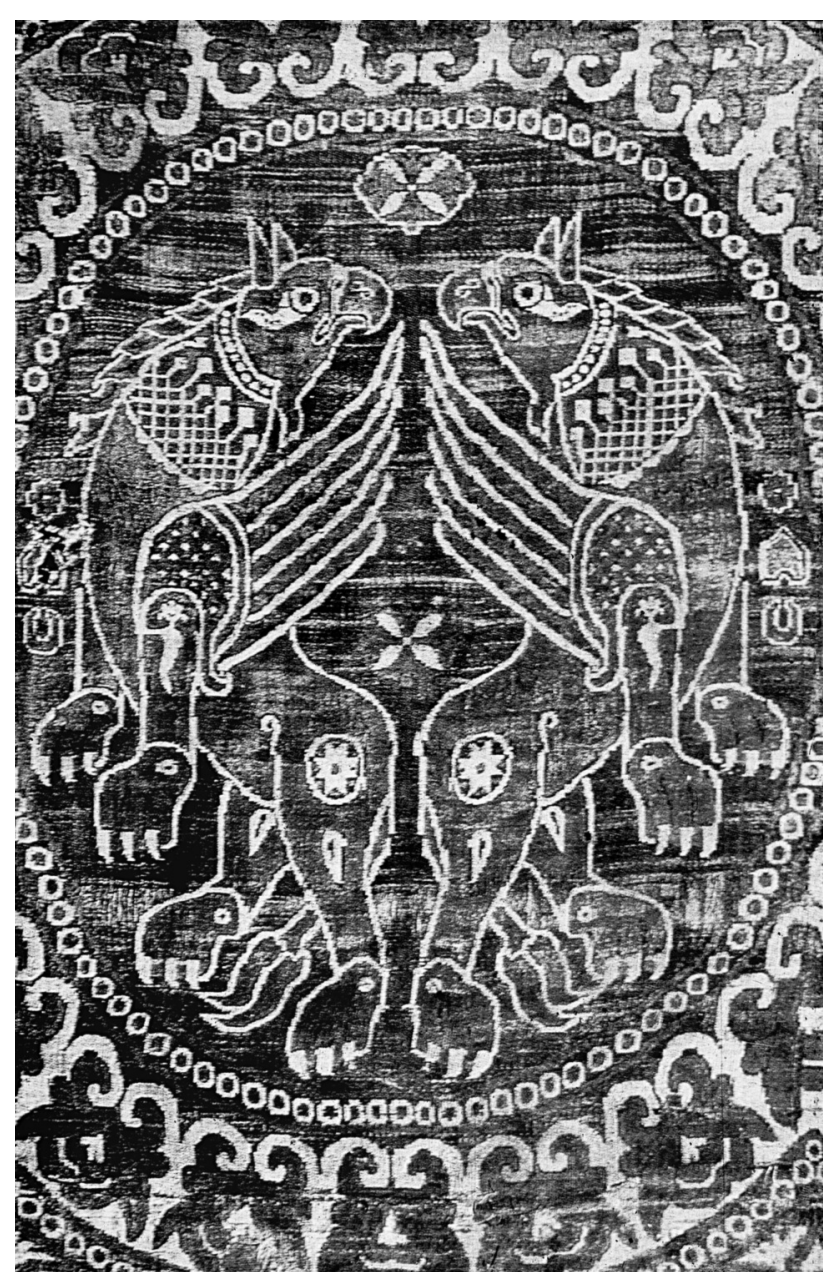

Fig. 5. Sitten, Cathedral treasury. Griffin silk, 10th century, Byzantine.

\section{b. Court Codes of Identification}

At Court a strict hierarchy was rendered visible through use of very specific different silk costumes of office for each rank of official, as was detailed by Pseudo Codinus for the 14th century. ${ }^{41}$ This code allowed the Emperor to distance himself from the court, whilst at the same time enabling Imperial control to be imposed over courtiers. In the same manner the civil service, not least the military, were distinguished through use of silk uniforms.

\section{c. Regulation of the Public Finances}

Precious cloth served a role in the regulation of public finances in as far as victorious generals of distinction were rewarded by presentation of valuable Imperial purple military tunics or skaramangia, and part of their pay also could be received in silk from the Emperor, when the occasion de- manded. ${ }^{42}$ Silk served as a currency with a value equating to that of gold. ${ }^{43}$ As such silk cloth was used to seal alliances and to ransom prisoners in the field of Byzantine foreign policy. ${ }^{44}$ As part of Byzantine economic policy, silk trade taxes were shared between Byzantium and the Arabs at Aleppo for a period of time. ${ }^{45}$ Tax was also levied on the sale of precious silks in Constantinople in the 10th century. ${ }^{46}$

\section{d. Civilising Associations of Byzantine Governance}

In 968, the Byzantine Emperor Nicephoros informed the Latin envoy Luitprand, when he failed to smuggle out of Byzantium, a piece of forbidden purple silk: "As we the Byzantines surpass all other nations in wealth and wisdom, so it is right that we should surpass them in dress. Those who are unique in the grace of their virtue, should also be unique in the beauty of their rainment." 47

Clearly, Byzantine precious cloth was considered an attribute of Byzantine culture and a civilising element. Inscribed Imperial, diplomatic silks sent to the West to promote marriage alliances, bore Hellenic striding lion motifs, and were used to remind the receiver of the ancient legacy of Imperial authority. One example is the Siegburg Lion silk, precisely datable to AD $921-923^{48}$ (Fig. 6).

\footnotetext{
${ }^{41}$ See n. 39 above.

${ }^{42}$ The distribution of skaramangia and coin as rhogai were detailed by Liutprand of Cremona. See Liutprand of Cremona, Antapodosis
} (ed. J. Becker), Die Werke Liudprands von Cremona, Hanover Leipzig 1915, VI.10, 157-158 as cited together with other instances of largesse also by M. F. Hendy, Studies in the Byzantine Monetary Economy c. 300-1450, Cambridge 1985, 191, 193 and 229.

${ }^{43}$ On an economic level silk served as currency in place of gold for payment of bills. See S. D. Goitein, A Mediterranean Society, I-II, London 1967, I, 201 and n. 40 citing the source TS12.366, 1.12 and Bodleian library, Oxford manuscript Heb. D66 (Cat 2878) f. 52*.

${ }^{44}$ One thousand silk costumes were amongst other priceless objects, that were sent by the Emperor Constantine IX to the Caliph Al Mustensir in 1045. Refer to, Ibn al-Zubayr, Kitab al-Dhaka ir wa-ltuhaf (ed. M. Hamidullah), 74-77. On gifts from Byzantine Emperors sent as diplomatic gifts see M. Hamidullah, "Nouveaux documents sur les rapports de l'Europe aves l'Orient Musulman au Moyen Âge," Arabica 7 (1960), 281-300.

${ }^{45}$ W. A. Farag, "The Aleppo Question," BMGS 14 (1990), 44-60.

${ }^{46}$ In the 10th century in the Capital, silk garments worth above ten nomismata, had to be stamped by the Eparch of Constantinople. See Koder, op.cit. (n. 13), section 8.1, p. 102-103.

${ }^{47}$ Liutprand Antapodosis, chapter 54, see translation in F. A. Wright, The Works of Liudprand of Cremona, London 1930.

${ }^{48}$ Muthesius, Byzantine Silk Weaving, op.cit. (n. 1), study IV, 34-38 and 40-41 with n. 1-33. 


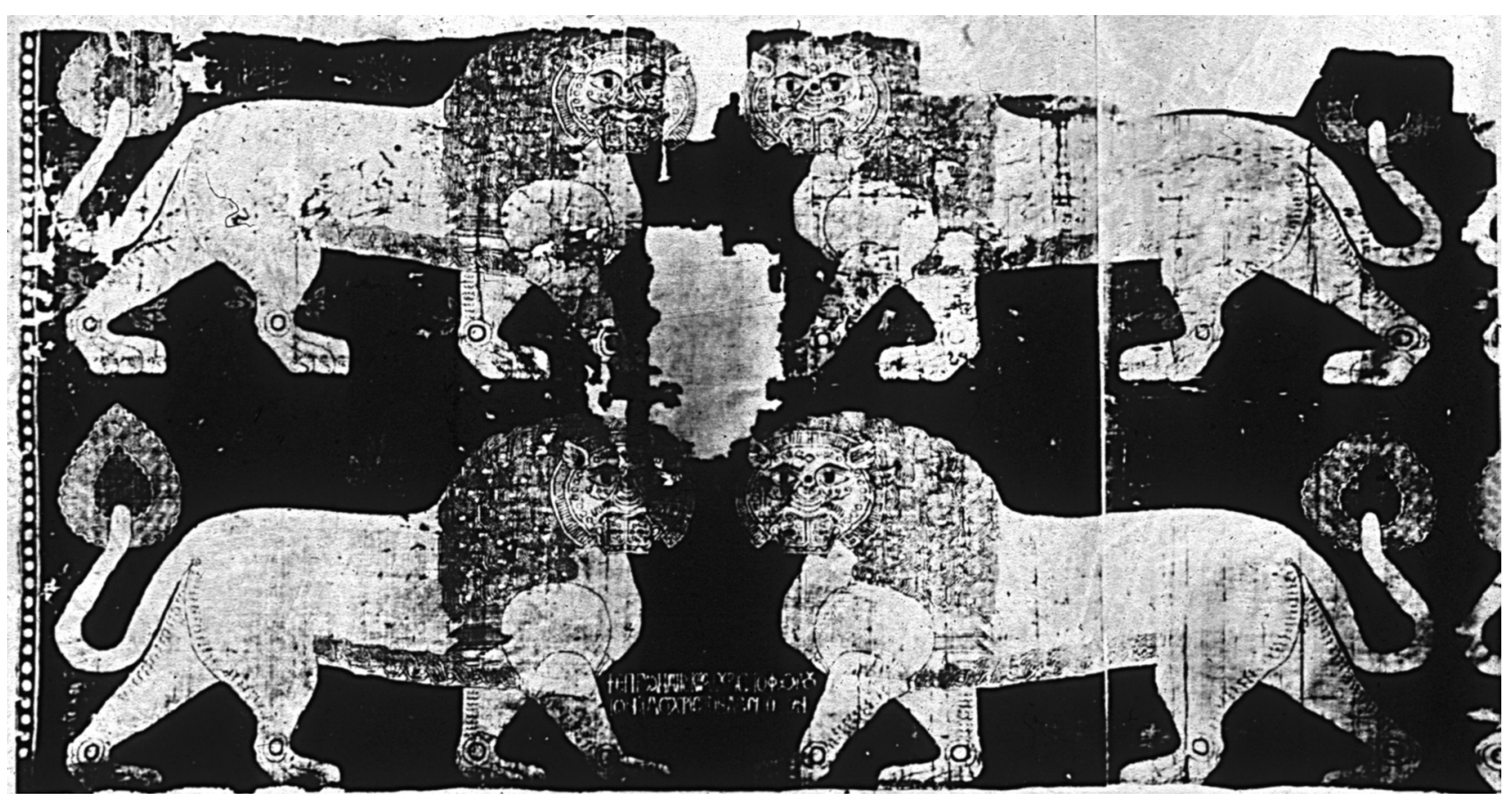

Fig. 6. Berlin, Schloss Köpenick. Siegburg Lion silk, AD 921-931, Byzantine.

e. Sacral Associations of Imperial Rule

Precious textiles played an important part in emphasis of the sacral element of Imperial rule from an early date. Various Imperial figures devoted themselves to the promotion of cults of the Virgin and of Christ, allied to the veneration of cloth relics: not least, the girdle, veil, and mantle of the Virgin, and the Shroud and Mandylion of Christ. ${ }^{49}$ Imperial civic ceremony was transferred to a Christian milieu.

In the 6th century a silk altar cloth presented to Hagia Sophia by Emperor Justinian was embroidered with scenes of the life of Christ bordered by scenes of victory featuring the Emperor and in the period up to the 12th century, the Emperors were seen as intercessors between God and man. ${ }^{50}$ Michael Psellos wrote of the Emperor Constantine Monomachos: "What the Creator is in relation to you, this you may be in relation to us." 51 This attitude extended to the concept of earthly court as mirror of heavenly court above. ${ }^{52}$ By the 13th century, precious textiles as used by the Church, chose to emphasise a different view of the sacral role of the Emperor. Religious vestments with the image of Christ Patriarch appeared: a reference to the intermediary role of the Church as intercessor between God and his people, without reference to Imperial "Divine right." A Post Byzantine example occurs on a polos at Hagia Aikaterine's monastery, Mount Sinai (Fig.
7). ${ }^{53}$ Whilst up to the time of the Latin conquest in AD 1204 the Emperor might have been viewed as intercessor between God and the people, after this time the balance of power between Church and State had altered as was reflected in ecclesiastical embroidery. ${ }^{54}$

\footnotetext{
${ }^{49}$ For discussion of the relics of the Virgin see M. Jugie, La mort et l'assomption de la Sainte Vierge, Rome 1944, 688-707. On the mandylion see $O D B$ II, 1282-1283 citing an extensive bibliography on the subject.

${ }^{50}$ Paulus Silentarius, Descr. S. Sophiae (ed. P. Friedländer), Leipzig Berlin 1912, 755-805, translated by C. Mango, The Art of the Byzantine Empire 312-1453. Sources and Documents, New Jersey 1972, 88-89. ${ }^{51}$ Michaelis Pselli, Scriptora minora (eds E. Kurtz - F. Drexl), I, Milan 1936, 31.1-3.

${ }^{52}$ H. Maguire, "The Heavenly Court," Byzantine Court Culture from 829-1204 (ed. H. Maguire), Washington 1997, 247-258.

${ }^{53}$ Dagron, op.cit. (n. 36), 295-312.

${ }^{54}$ Christ as Patriarch was a common motif on later Byzantine and post-Byzantine embroideries. See Muthesius, Studies in Byzantine, Islamic and Near Eastern Silk Weaving, op.cit. (n. 1), study XVII, 311 and pl. 31-33.
} 


\section{B. Religious Doctrine}

a. Byzantium as Ecumenical State

The concept of Byzantium as Ecumenical State involved the amalgamation of Hellenistic ideas about the world, with Christian beliefs about the divine nature of Imperial rule. The concept referred to a civilised world within the boundaries of the Roman Empire, whose Christian centre was the "new Rome," Constantinople. ${ }^{55}$ Successive Byzantine Emperors from the time of Constantine the Great, the founder of "new Rome' identified with the concept as part of Greek tradition and culture. Set against this idea of divine right of Emperors was the question of the spiritual authority of the Church. ${ }^{56}$

\section{b. Spiritual Authority of the Church}

Turning from political ideology to religious belief and the spiritual authority of the Church, the moral element of the use of precious cloth is relevant. John Chrysostom, whilst supporting social distinctions in dress (such as the difference in status of master and slave), called for propriety in dress codes across social classes ${ }^{57}$ Asterios, Bishop of Amasia castigated the local population for wearing costumes covered in secular or even in religious designs, retorting that, "By doing this, these people believe they are being pious and are dressing in clothing which will please God. If they were to listen to my advice, they would sell these garments and instead honour what God created in his living image." 58

On the other hand, Byzantine ecclesiastical vestiture, fashioned out of precious cloth, was considered to signal Church hierarchy and spiritual authority. One important 13th century Byzantine vestment is in the Museo Sacro of the Vatican in Rome (Fig. 8). On the spiritual side, such vestments were considered to symbolise aspects of Christ's suffering taken on by the priesthood, serving as intercessory agent for the salvation of mankind. The epimanikia for example, symbolised the shackles attached to the wrist of Christ before he was led out to his Passion. ${ }^{59}$

\section{c. Spiritual Image of Precious Cloth}

From an early period a spiritual dimension was attached to weaving cloth.

In AD 428-429 Proclus, later Patriarch of Constantinople, wrote a homily for the Feast of the Virginity of Mary. In an extensive weaving metaphor he termed the Virgin, "Handmaid and mother, maiden and heaven, only bridge to mankind: the awesome loom of salvation on which the robe

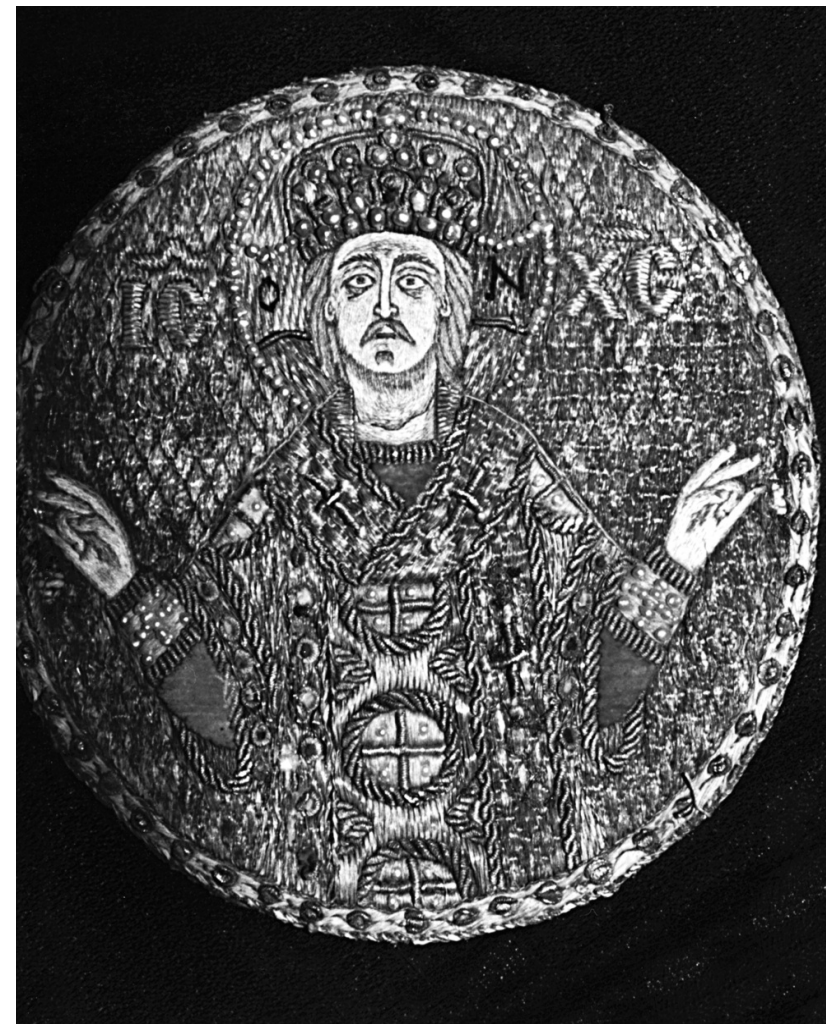

Fig. 7. Sinai, monastery of Hagia Aikaterine. Christ Patriarch silk, Post Byzantine.

\footnotetext{
${ }^{55}$ For the concept of Constantinople as the "New Rome" see Kaldellis, op.cit. (n. 7), 43-44, 52, 59, 61-62 with n. 58, 71-71, 81-82. See also, S. Calderone, "Constantinopoli: la seconda Roma," Storia di Roma (eds A. Momigliano - A. Schiavone), V, III, part I, Turin 1993, 723-749. Further see F. Dölger, "Rom in der Gedankenwelt der Byzantiner," in F. Dölger, Byzanz und die europäische Staatenwelt, Ettal 1953, 70-115.

${ }^{56}$ The rule by "divine right" claims of the Emperors was brought into focus with the fall of the Empire to the Latin West in 1204. For the effect on relations between Church and State see M. Angold, Church and Society in Byzantium under the Comneni 1081-1261, Cambridge 1995, chapter 25, "Imperial authority and the Orthodox Church," on p. 530-563.

${ }^{57}$ John Chrysostomos, In epistulam ad Hebraeos homilia, PG 63.200.

${ }^{58}$ Asterius of Amaseia, Homil. 1, PG 40, 165-168, translated by Mango, op.cit. (n. 50), 50-51.

${ }^{59}$ On liturgical vestments including epimanikia see T. Papas, Studien zur Geschichte der Messgewänder im byzantinischen Ritus, Munich 1965; J. Braun, Die liturgische Gewandung im Occident und Orient, Darmstadt 1964, and P. Bernadakis, "Les ornaments liturgiques chez les grecs," EO 5 (1901-1902), 129-139.
} 
of union was mysteriously woven: whose weaver was the Holy Spirit, the workman the power that overshadowed from on high, the wool the ancient fleece of Adam, the fabric the unsullied flesh of the Virgin, the shuttle the immeasurable grace of him who wove it, and the craftsman the Word who entered through the ear." 60

Saint Theodoret of Cyrrus in a 5th century homily powerfully described the arts of weaving and embroidery as gifts from God. ${ }^{61}$

For the period up to the 12th century, precious Byzantine ecclesiastical cloths with religious imagery do not survive in number. There are liturgical cloths with the Communion of the Apostles at Halberstadt, and descriptions in the Liber Pontificalis indicate the existence of woven Christian narrative scenes on silks in use in Rome during the period of Iconoclasm. ${ }^{62}$ Where these were woven is unclear. The Vatican Annunciation and Nativity silks are Byzantine twill weave fabrics woven most probably in Constantinople post second Iconoclasm (Fig. 9). ${ }^{63}$ This narrative Christian textile tradition may hark back to the types of textiles described by Bishop Asterios of Amasia in the 5th century. ${ }^{64}$ What is clear is that these narrative Christian scenes embodied concepts of human salvation and that this aspect of Orthodox faith, was further developed on liturgical furnishings, from the 12th century forwards.

\section{d. Liturgical Intercession}

The early development of the liturgy in Byzantium from the 6th to the 7th century saw the emergence of the Constantinopolitan rite, and an engagement with mystic cosmic symbolism celebrated through the liturgy, under the influence of the Mystagogy of Saint Maximos the Confessor ( $c a$. 630) ${ }^{65}$ Urban stational, liturgical rites (with the procession of the Eucharist between distant churches) were replaced by celebration of the Eucharist within small, enclosed naves. ${ }^{66}$ Saint Germanos, Patriarch of Constantinople ( $c a$. 730) stressed the Eucharist as not only mystical rite but also as rite of literal salvation in Christ. ${ }^{67}$ This new sense of realism called for greater appreciation of the humanity of Christ, and for realistic images to supplement purely symbolic religious imagery.

A mid-Byzantine Church decoration programme was devised to celebrate both the divine and the human Natures of Christ. ${ }^{68}$ Christ Pantocrator appeared in the dome, and the Virgin as intercessor in the apse, flanked by the Communion of the Apostles; a symbolic representation of the Eucharist. Christ's humanity was symbolised through Christological scenes placed on the pendentives of the central cupola (An-

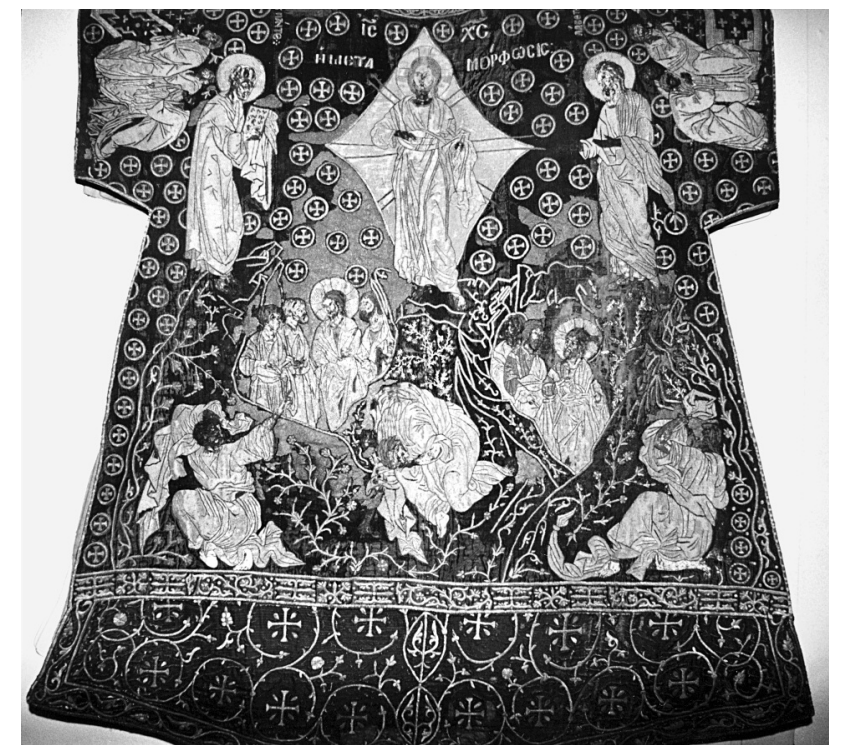

Fig. 8. Rome, Vatican, Museo Sacro. Dalmatic, 13th century, Byzantine.

nunciation, Nativity, Presentation and Baptism) complemented by further scenes from his life set along the nave. The church decoration emphasised the liturgical intercession,

\footnotetext{
${ }^{60}$ Proclus $P G$ 65, 681 as cited in V. Limberis, Divine heiress. The Virgin Mary and the Creation of Christian Constantinople, London 1994, 85-86.

${ }^{61}$ Theodoret of Cyrrhus, De providentia oratio IV, PG 83, 617-620, discussed in Muthesius, Byzantine Silk Weaving, op.cit. (n. 1), 23-24. ${ }^{6}$ Der Heilige Schatz im Dom zu Halberstadt (eds H. Meller - I. Mundt - B. E. Hans Schmuhl), Regensburg 2008, catalogue numbers 81-82 on p. 282-285. For the Liber Pontificalis silks see, Muthesius, Byzantine Silk Weaving, op.cit. (n. 1), 124-125 with reference to Liber Pontificalis (ed. L. Duchesne), 1-2, Paris 1884-1892 and 1955. For English translation see, R. Davis, The Lives of the Eighth Century Popes (Liber Pontificalis), Liverpool 1992.

${ }^{63}$ Muthesius, Byzantine Silk Weaving, op.cit. (n. 1), 67, catalogue M35, with plates 20A and 20B.

${ }^{64}$ See note 58 above.

${ }^{65}$ Refer to, R. Taft, Liturgy in Byzantium and Beyond, Aldershot 1995, chapter 1 on p. 45-75 for the liturgy of Hagia Sophia pre Iconoclasm. Also, for a discussion on the theology of Maximus see A. Louth, Maximus the Confessor, London 1996, chapter 2, p. 19-32, with a bibliography on p. 220-225.

${ }^{66}$ R. Janin, "Les processions religieuses à Byzance,” REB 24 (1966), 69-88. Further consult J. F. Baldovin, "The Urban Character of Christian Worship. The Origins, Development and Meaning of the Stational Liturgy," OCA 228 (1987), chapter 6.

${ }^{67}$ See P. Meyendorff, St. Germanus of Constantinople. On the Divine Liturgy, New York 1984.

${ }^{68}$ E. Giordani, "Das mittelbyzantinische Ausschmückungs-system als Ausdruck hieratischen Bild Programms," JÖBG 1 (1951), 103-134.
} 


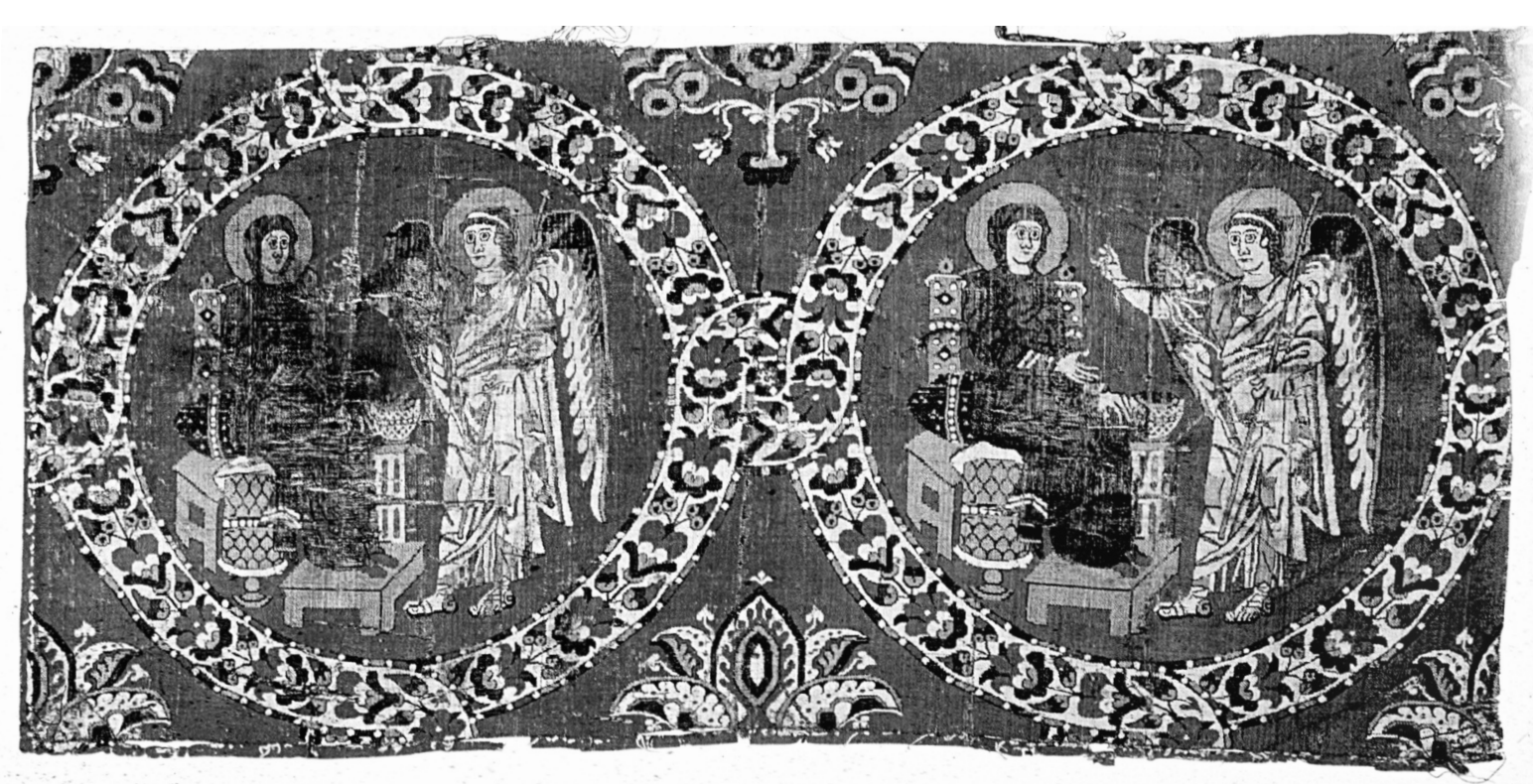

Fig. 9. Rome, Vatican, Museo Sacro. Annunciation and Nativity silk, later 9th century, Byzantine.

which enabled the salvation of Mankind. In turn, doctrinal concepts about human salvation were transmitted upon precious church furnishings used for the re-enactment of the liturgy. Christ as "intercessor for the salvation of Man" was symbolised in scenes of the Anastasis, the Communion of the apostles, the Creation of Adam, the Dead Christ (which was developed into the Epitaphios Threnos or Lamentation scene), and the Melismos (Christ child upon the altar image). Shown here is a 15 th century Epitaphios from the monastery of Hagios Ioannes on Patmos (Fig. 10). In the same way Trinitarian doctrine was reflected on imagery of later Byzantine gold embroidery. ${ }^{69}$

\section{e. Orthodoxy and National Identity}

The continuation of traditional themes on religious gold embroidery into Post Byzantine times, raises the question of the relationship between Orthodoxy and later Greek identity. Indeed, it calls for deeper examination of the question raised by Kaldellis about Byzantine identity as "nation state," as against "Empire" after the 13th century, but this cannot be explored further here. ${ }^{70}$

To sum up the evidence about belief systems in relation to precious cloth, the theoretical model once more can be seen to provide a useful framework. Dual concepts of Imperial secular/divine power were expressed through cloth, and ceremonial practices associated with the textiles did allow for the "cultural transmission" of these concepts across different strata of Byzantine society, and also beyond to an International audience. Similarly, religious doctrines and beliefs were embedded in Christian imagery of religious cloths, and liturgical practices allowed for their "cultural transmission" between minds. The role of precious cloths as communicators of political ideology and of religious doctrine is clear. It remains to examine precious cloth in the context of Social Systems.

\section{Social Processes}

\section{A. Social Communication}

a. Social Stratification and Social Interaction

Social stratification was discussed above under "dress," but it should be remarked that historical sources do not provide a standard definition of what were considered the strata of Byzantine society. The most comprehensive definition with division into "upper, middling and lower class" is perhaps also the most general. ${ }^{71}$ Others saw the division as between landowners, bureaucrats, manufacturers and traders and artisans. In general,

\footnotetext{
${ }^{69}$ See A. Muthesius, "Tribute to Donald King: Silken Embroidery and Orthodox Faith in Byzantium," in Muthesius, Byzantine, Islamic and Near Eastern Silk Weaving, op.cit. (n. 1), chapter V, 52-69.

${ }^{70}$ Kaldellis, op.cit. (n. 7), 317-388.

${ }^{71}$ On Byzantine society see J. Shepherd, "Closing Address: Invisible Byzantiums," Material Culture and Well-Being in Byzantium, op.cit. (n. 13), 225-234.
} 


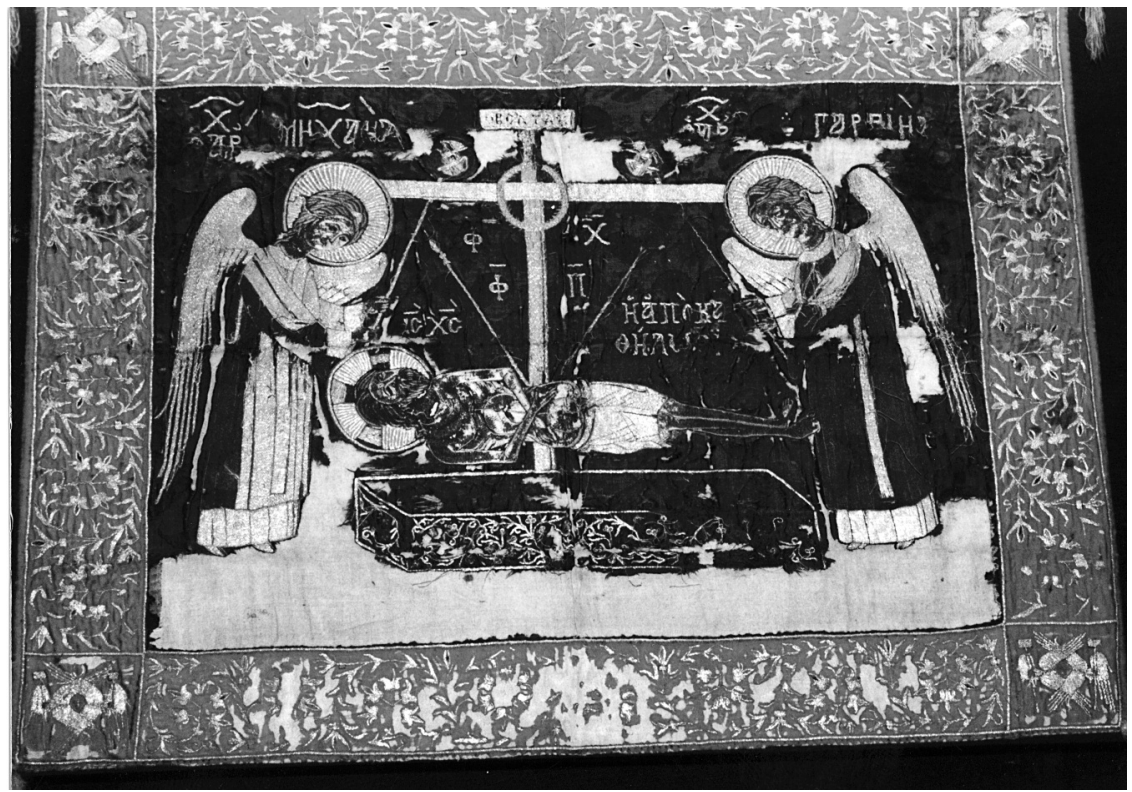

Fig. 10. Patmos, monastery of Hagios Ioannis. Epitaphios, 15th century, Byzantine.

there were notions that manual labour indicated inferior class, and that noble birth and inherited wealth were signs of upper class, but meanwhile notions about the middling class, varied over time and according to context. Social mobility was granted to the manufacturing class up to a point but by the time members of that strata of Byzantine society had reached the Senate, in the 11th century an Imperial clamp-down was imposed to prevent the rise of the "middling class." mobility was gained through Imperial favour and the award of civil office, so that the individual could then rise through the civil ranks. Grants of favour, monetary and material often accompanied the award of office.

\section{B. Guilds and Occupational Kinship}

A special mention must be made of the guilds in Byzantium, including those of the silk workers, the silk retailers and the merchants of imported silks. The present author has produced a chart to illustrate the organisation of the silk industry as shown here (Fig. 11). The regulations of the Book of the Prefect indicate that these guilds operated as a form of occupational kinship within confined urban spaces and that they observed Imperial regulation of their behaviour, their standards of production, retailing and distribution. ${ }^{73}$ The regulations included civic duties such as the production of certain "forbidden silks" destined only for Imperial use; and the decoration of the
Capital for Imperial parades. These duties engendered a sense of civic duty and civic pride in the guildsmen and allowed for the public display of the fine textiles produced by the guilds. Other guilds and bodies held less desirable festivals that sometimes were condemned and eventually banned by religious and civic authorities. The festival of the Notaries, for example, involved cross-dressing in silks, drunken revels and lewd innuendo. ${ }^{74}$ The popular festival of "Agathe" on the other hand, celebrated the good work of female weavers, in the form of a pageant re-enacting weaving processes. ${ }^{75}$ Despite its echo of the notion of "labour as spiritual enlightenment," and perhaps because of pagan associations, this festival eventually died out. All these different forms of public display involved precious or less precious cloths and these communicated messages about "belonging," profession, status, civic duty and urban

\footnotetext{
${ }^{72}$ The influence of the mercantile and artisan classes and the suppression of their influence under Alexius I are discussed by Hendy, op.cit. (n. 42), 578-590 and see especially 584 with source reference in n. 136. ${ }^{73}$ See A. Muthesius, "From Seed to Samite. Aspects of Byzantine Silk Production," Ancient and Medieval Textiles. Studies in Honour of Donald King (eds L. Monnas - H. Granger-Taylor), special volume Textile History 20, 2 (1989), 135-149.

${ }^{74}$ See A. Laiou, "The Festival of 'Agathe' Comments on the Life of Constantinopolitan Women," in A. Laiou, Gender, Society and Economic Life in Byzantium, Aldershot 1992, chapter 3, p. 121-122. ${ }^{75}$ Ibid., 111-122.
} 
identity across the "middling" strata of Byzantine society. In the same way social messages were probably built into religious fairs, such as that of Hagios Demetrios, in Thessaloniki, where goods including various grades of textiles could be purchased. ${ }^{76}$ Lack of social responsibility, on occasion, also was demonstrated in conjunction with precious cloth. There are documentary references to the desecration of the dead and/or of graves, involving theft of precious burial clothing. ${ }^{77}$

\section{Social Mobility, Social Inequality, Wealth Distribution and Greed}

\section{a. Provincial Aristocracy}

The social mobility occasioned through the award of civic office was mentioned above and the use of precious textiles amongst this category of individual was profound. The military aristocracy in particular, received precious Imperial silk costumes and these were donated to their private religious foundations. Imperial purple skaramangia were recycled as altar cloths and the inventories of these foundations were full of descriptions of rich silk furnishings, embroidered with religious images, and providing an indication of the scale of aristocratic silk patronage and material wealth of this strata of society. ${ }^{78}$

\section{b. Monasteries}

In Byzantium, notions of "Christian salvation" and of "spiritual edification gained through material deprivation" were employed to sustain the concept of a just type of social stratification, which underpinned systems of unequal wealth distribution. ${ }^{79}$ However, these beliefs did not extend to the exclusion of the acquisition of wealth by monastic foundations. Vast treasuries of precious textiles were built up through Imperial and aristocratic, religious and lay patronage. ${ }^{80}$ The revived, "Neo-Platonic" concept of Pseudo Dionysius, concerning the reflection of the divine light of God through the use of religious objects made of precious materials, no doubt was influential here. ${ }^{81}$

c, d, e. Manufacturers, Urban Citizens, Sumptuary Legislation In spite of what has been said above about the status of the manufacturing classes, the widow Danielis was able to present great numbers of precious textiles to the Emperor Basil I at the time of his accession to the throne. ${ }^{82}$ This raises interesting questions about the status of women and their role in wealth creation in Byzantium through textile production, but lack of documentary sources prevents further comment. Similarly, one wonders about the role of aristocratic women in the production of domestic silk textiles in their homes. The regulation in the Book of the Prefect of this form of production, suggests that the sale of valuable

${ }^{76}$ S. Vryonis, "The Panegyris of the Byzantine Saint," The Byzantine
Saint. Proceedings of the Fourteenth Spring Symposium of Byzantine
Studies. Sobornost Incorporating Eastern Churches Review (ed. S.
Hackel) [Studies Supplementary to Sobornost 5], 1981, 196-226, es-
pecially 202-204. The panegyris of Hagios Demetrios was described
in the Timarione see, R. Romano, Pseudo-Luciano. Timarione. Testo
critico, introduzione, traduzione, commentario e lessico, Napoli 1974, 53-59, as cited by Vryonis.

${ }^{77}$ Bodies were plundered for their garments pre burial in the cemetery of Saint Luke in Constantinople. See, Oikonomides, "Life and Society," op.cit. (n. 34), 12.

${ }^{78}$ For instance, consider the wills of Symbatius Gregororios Pacourianos and his wife Kale. See, P. Gautier, "Le typikon du Sébaste Grégoire Pakourianos," REB 42 (1984), 5-145 with list of gifts on 35-44. Earlier compare, P. Lemerle, "Le typikon de Grégoire Pakourianos," Cinq études sur le XIe siècle byzantin, III, Paris 1977, 113-191, and L. Petit, Typikon de Grégoire Pacourianos pour le monastère de Pétritzos (Bačkovo) en Bulgarie [Vizantijskij Vrememnik 53], 1904, 24-63. Also relevant is the will of the Hypatos Eustathios Boilas. Refer to, J. Lemerle, "Le Testament d'Eustathios Boilas (1059)," Cinq études, op.cit., I, 15-66.

${ }^{79}$ For the concept of the "Christian Self" relevant here, see D. Kruger, "Romanos the Melodist and the Christian Self in Byzantium," Proceedings of the Twenty First International Congress of Byzantine Studies (London, 21-26 August 2006), I, Aldershot 2006, 255-274 and see especially, 262-265. On "salvation" and the evils of materialism as stated in sermons see, Preacher and Audience. Studies in Early Christian and Byzantine Homiletics (eds M. B. Cunningham - P. Allen), Leiden - Boston - Cologne 1998.

${ }^{80}$ For silks in situ in monasteries consider for instance, Treasures of Mount Athos (exhibition catalogue), Thessaloniki 1997, section 11, p. 379-417; The Holy and Great Monastery of Vatopaidi, I-II, Mount Athos 1998, II, 420-457; E. Vlachopoulou-Karabina, Gold Embroideries. Holy Monastery of Iveron, Mount Athos 1998. A small number of silks from Sinai were published in Sinai. Treasures of the Monastery (ed. K. A. Manafis), Athens 1990, by M. Theocharis, on p. 231-259. The entire collection of the monastery of Hagia Aikaterine has been catalogued by the present author and is under publication. Further articles, too many to list here, on gold embroidery, are by M. Theocharis, and the seminal work on the gold embroideries in situ is by, G. Millet, Broderies religieuses de style byzantin, I-II, Paris 19391947. See also P. Johnstone, The Byzantine Tradition in Church Embroidery, London 1967.

${ }^{81}$ Hypatius of Ephesus explained that material adornment could serve to lead human thought up to the Godhead. See, Hypatius of Ephesus, Miscellaneous Enquiries (ed. F. Diekamp), Patristica Orientalia Christiana Analecta 117 (1938), 127-129, as translated by Mango, op.cit. (n. 50), 116-117.

${ }^{82}$ Refer to Hendy, op.cit. (n. 42), 206-207 on the widow Danielis. Hendy cites, Continuation of Theophanes (ed. I. Bekker), Bonn 1938 [CSHB V], 11, 73-77, 226-228, 316-321. The widow Danielis presented major gifts to Basil I twice, once before and once following his promotion to Emperor. 


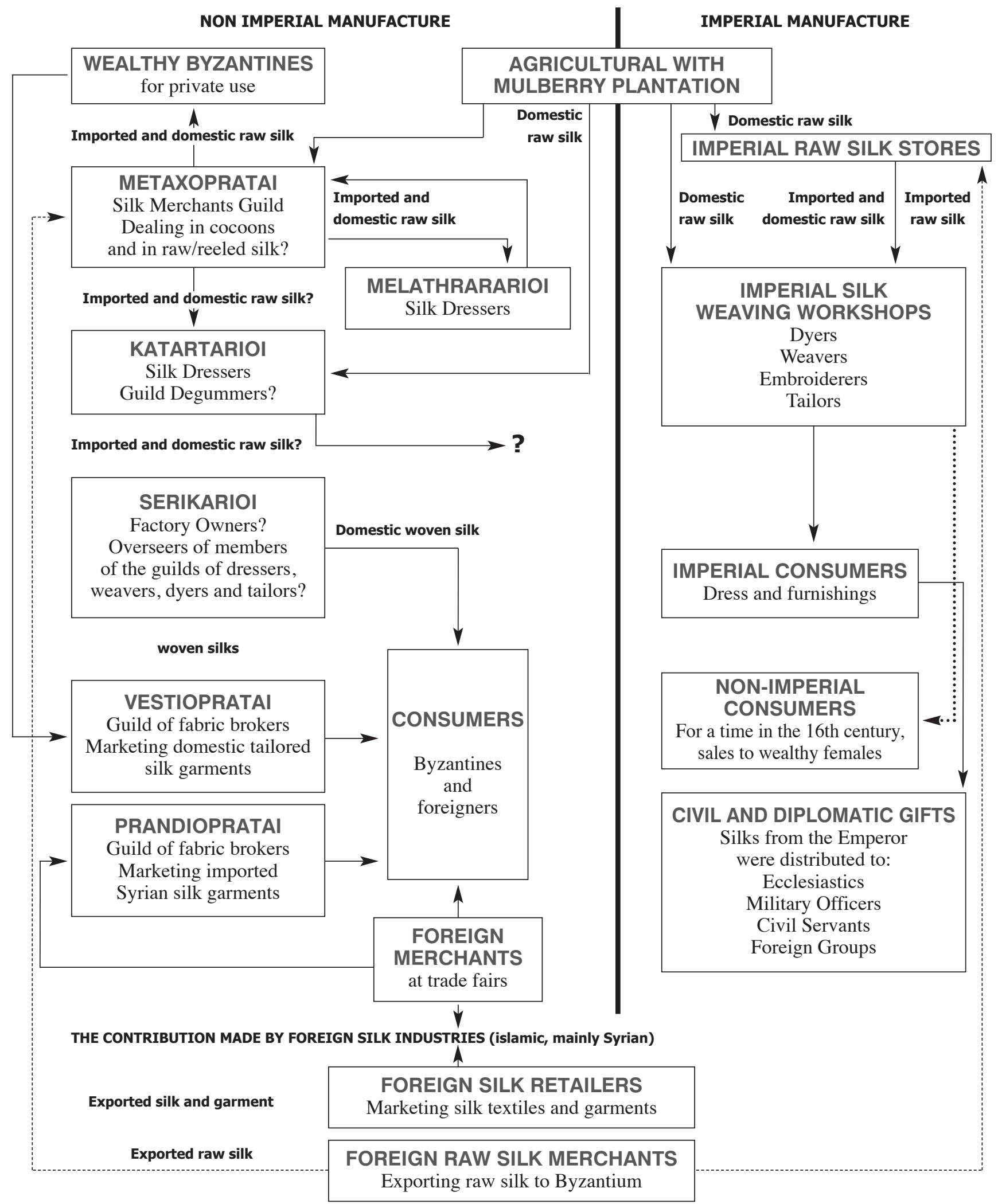

Fig. 11. "Organisation of the Byzantine Silk Industry" chart (Anna Muthesius). 


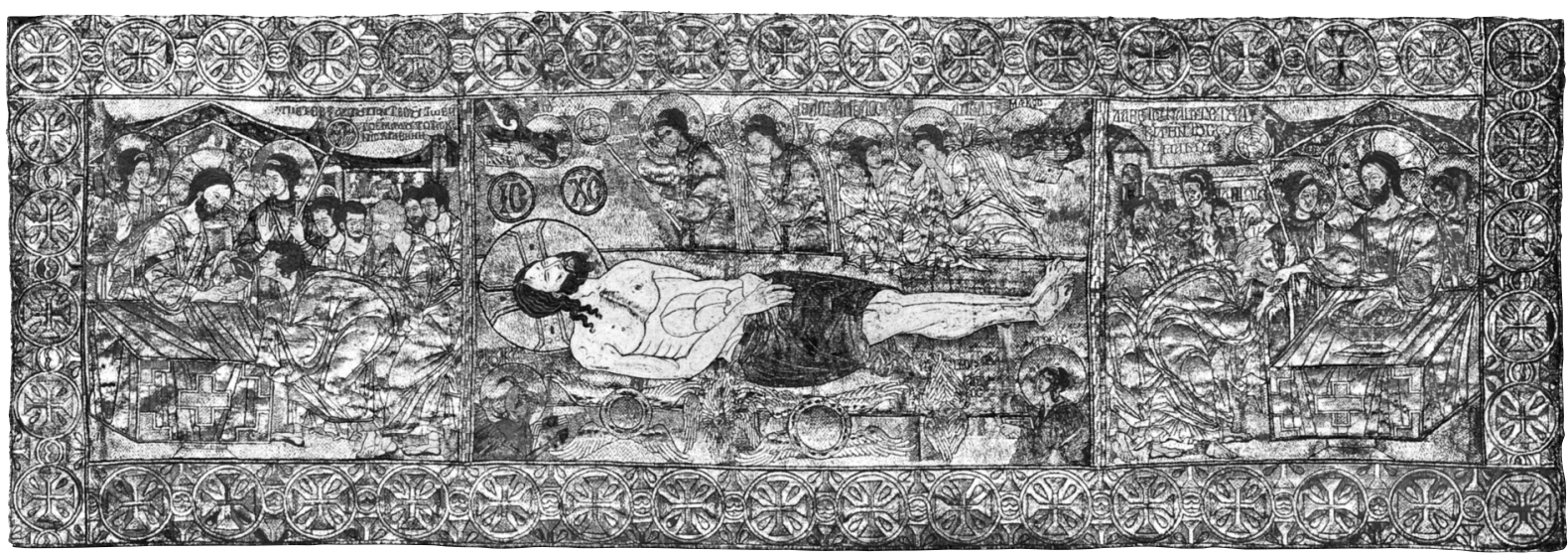

Fig. 12. Thessaloniki, Byzantine Museum. Thessaloniki Epitaphios, 13th to early 14th century, Byzantine.

silks from aristocratic sources had to be strictly prevented..$^{83}$

Lower down the social scale one imagines that dowries of Byzantine brides, like those of documented Cairo Geniza, Jewish brides, would have included silk garments and home furnishings (not least Byzantine silk sofas and bed covers of great worth), which in times of need could have been sold to raise funds. ${ }^{84}$ As discussed above, sumptuary legislation as such was not popular in Byzantium, and it may have been the potential for raising taxes on the sale of more costly fabrics, which enabled brides at home and abroad to amass rich silk dowries as a buffer against inflation and as a source of income in times of need.

From the evidence discussed in this third part of the paper, it can be said that precious cloth penetrated deeply into social systems in Byzantium and that clear messages about urban and regional identity, professional obligations and standards and occupational allegiance, civic duty and pride, morality and social responsibility were embedded in the appearance of and in the uses attached to these artefacts. Again the contemporary theory fits.

\section{Conclusion}

In conclusion it can be argued that contemporary cognitive theory regarding "cultural transmission" can be tested against written, visual and material evidence of historical civilisations. Here the theory has been tested in the context of "precious cloth" in Byzantium but equally this research approach could be applied to other areas of the study of material culture across time and space.

The paper has revolved around the subject of human engagement with the Byzantine material world. In answer to the question posed at the beginning of the paper concerning "enhancement of memory" and "cultural promotion" in relation to the use of precious cloth, two points can be made. Firstly, that "Memory" in the sense of knowledge of the historic past was inscribed upon precious cloth in all three ways under consideration: explicitly in the form of traditional motifs; and implicitly, as part of traditional institutional ceremony and ritual, and as crucial element of the fabric of social systems for communication of status, profession, and identity on many levels. Secondly, that the precious textiles served well to communicate concepts and norms about Byzantine political, religious and social organisation, operation and function, a basic tenet of "cultural transmission" in general. The Thessaloniki Epitaphios is an iconic example of the category of religious textiles heavily embedded with messages (Fig. 12).

The overall impression the evidence gives, is one of the "desire" of the Byzantines to present a picture of order across institutions (political and religious) and across social systems, through images on the precious cloths and by way of practices associated with them. To some extent precious cloths were used also to project the concept of perfect harmony between Church and State within a Christian "Empire" or later a Christian "nation state," even long after the decline of the Emperor's spiritual standing.

\footnotetext{
${ }^{83}$ Koder, op. cit. (n. 13), section 8.2 on p. 104-105.

${ }^{84}$ S. D. Goitein, A Mediterranean Society, I, London 1967, chapter 4, p. 105-138, and especially $115-116$ with appendix C on p. 297-309. Also note in particular the description of Byzantine silk brocade on p. 303 .
}

\section{Illustration Credits}

Archive of Anna Muthesius. 
Anna Muthesius

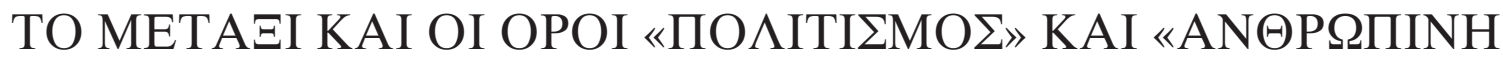

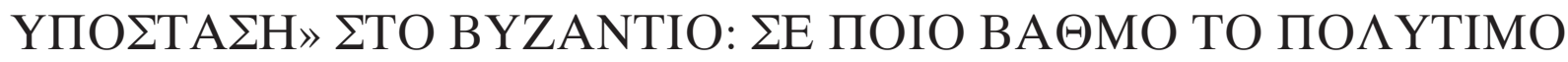 YФA $\Sigma$ MA ЕМП $\Lambda$ OYТI $\Sigma$ E TH «MNHMH» KAI $\triangle I A M O P \Phi \Omega \Sigma E$ «ПO $\Lambda$ ITI $\Sigma \mathrm{MO} » \Sigma \mathrm{TH}$ BYZANTINH AYTOKPATOPIA} (4os-15os aı́́vas);

$\Sigma$

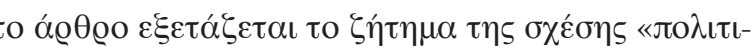

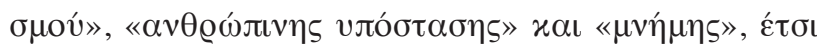

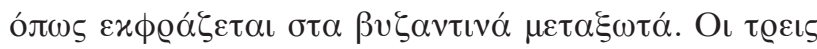

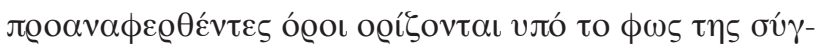

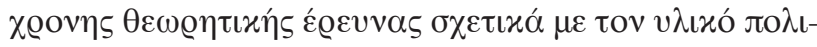

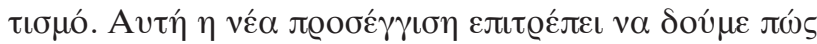

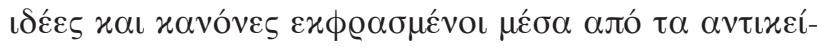

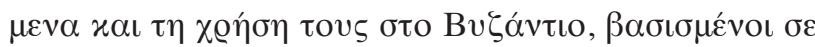

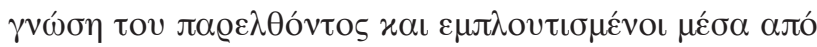

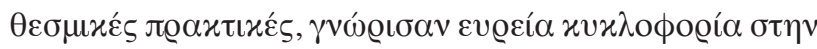

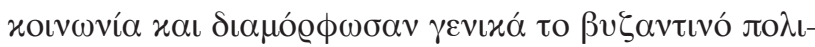

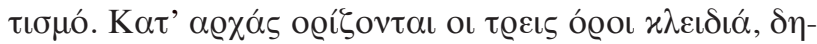

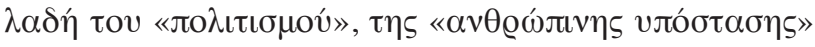

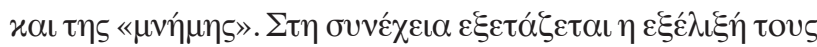

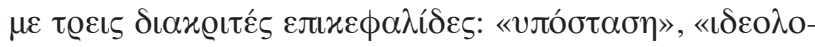

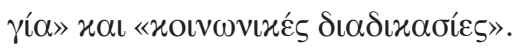

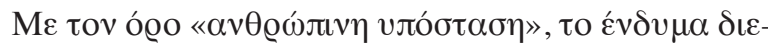

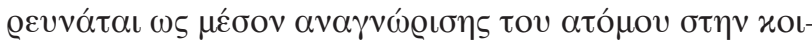

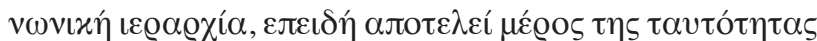

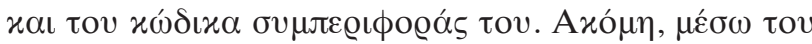

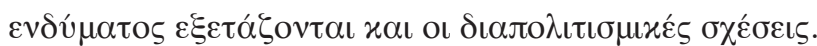

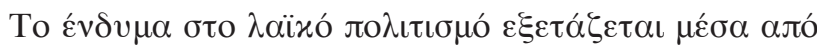

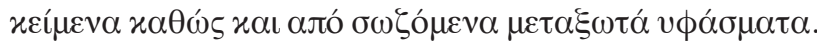

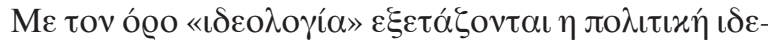

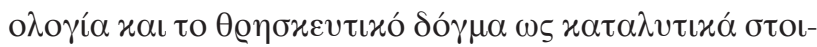

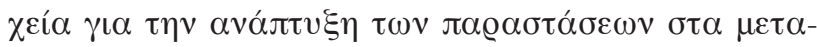

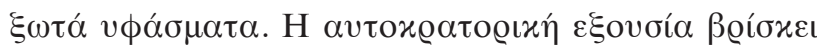

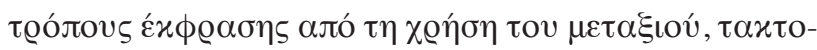

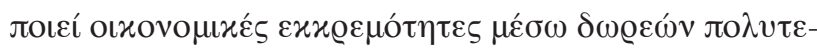

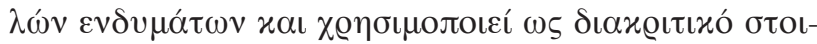

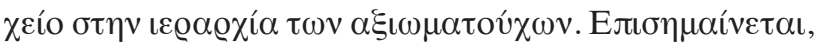

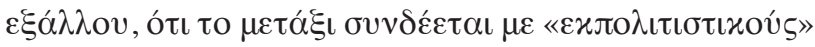

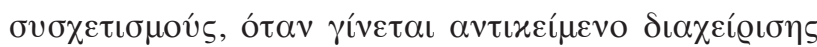

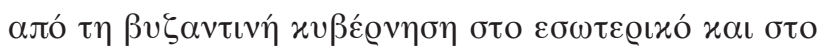

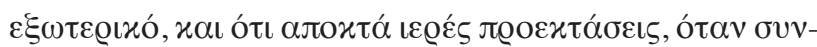

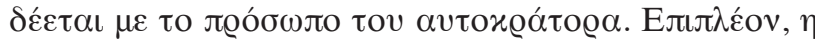

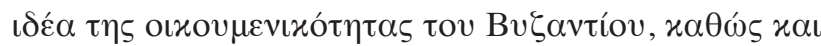

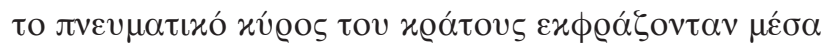

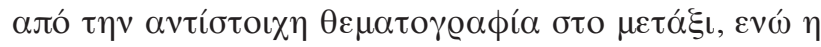

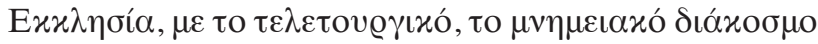

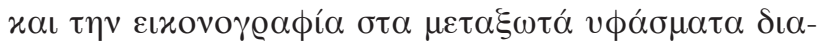

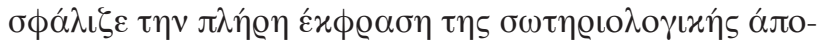

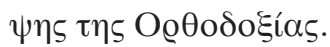

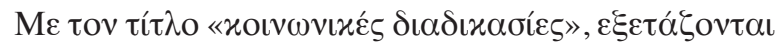

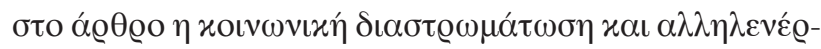

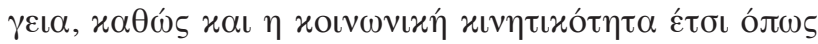

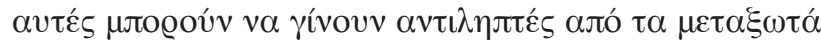

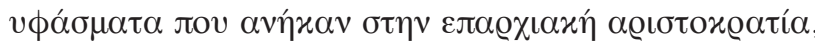

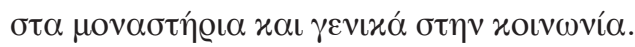

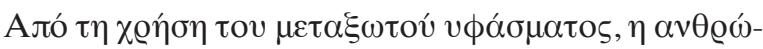

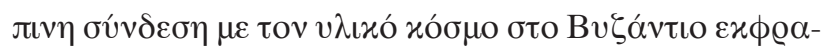

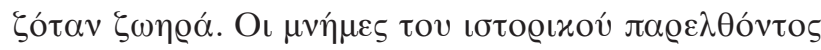

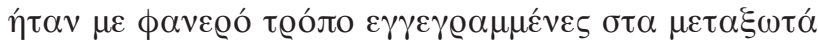

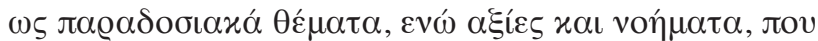

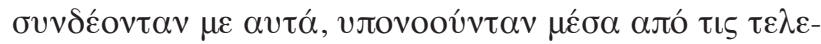

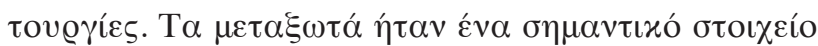

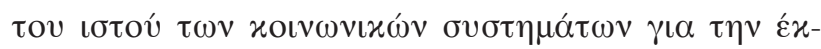

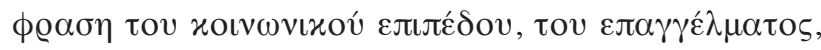

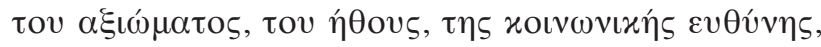

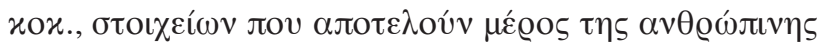

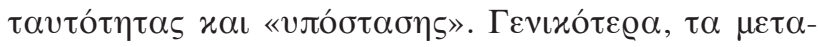

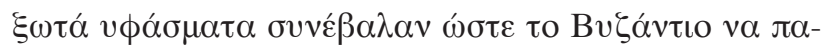

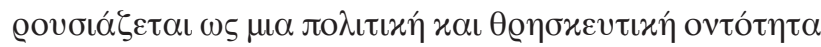

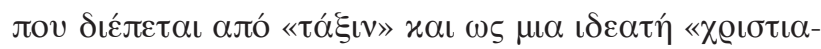

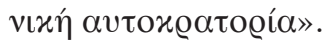

Fellow of the McDonald Institute for Archaeological Research, Fellow Commoner of Lucy Cavendish College, University of Cambridge, amuthesius@yahoo.co.uk 